\title{
Self-Regulation and Students Well-Being: A Systematic Review 2010-2020
}

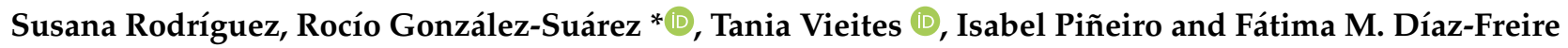

Department of Psychology, University of A Coruña, A Coruña 15008, Spain; susana.rodriguez1@udc.es (S.R.); t.vieites@udc.es (T.V.); isabel.pineiro.aguin@udc.es (I.P.); fatima.diaz@udc.es (F.M.D.-F.)

* Correspondence: rocio.gonzalez.suarez@udc.es; Tel.: +34-677-71-14-23

Citation: Rodríguez, S.; González-Suárez, R.; Vieites, T.; Piñeiro, I.; Díaz-Freire, F.M. Self-Regulation and Students Well-Being: A Systematic Review 2010-2020. Sustainability 2022, 14 2346. https://doi.org/10.3390/ su14042346

Academic Editor: Hyo Sun Jung

Received: 21 January 2022

Accepted: 16 February 2022

Published: 18 February 2022

Publisher's Note: MDPI stays neutral with regard to jurisdictional claims in published maps and institutional affiliations.

Copyright: (C) 2022 by the authors. Licensee MDPI, Basel, Switzerland. This article is an open access article distributed under the terms and conditions of the Creative Commons Attribution (CC BY) license (https:/ / creativecommons.org/licenses/by/ $4.0 /)$.

\begin{abstract}
In recent years, there has been particular interest in studying the relationship between student self-regulation and variables such as students' well-being, satisfaction, and school engagement. Although in other fields such as healthcare, self-regulation in different areas seems to influence individuals' well-being, this is not so well established in the educational arena. We performed a systematic search of research articles published between 2010 and 2020 which explored the relationships between self-regulation and student well-being. The present article presents a report of a systematic review of 14 research articles. The analysis showed that some executive functions and self-regulation strategies employed in the learning process, and some self-regulatory deficits are significantly associated with different dimensions of student well-being.
\end{abstract}

Keywords: learning self-regulation; well-being; quality of life; students; education; systematic review

\section{Background}

The interaction between self-regulation and various educational and personal variables has been extensively studied in educational psychology for over twenty years. The most important findings have tended to indicate that self-regulation of learning is significantly related to motivation, goal-setting, self-efficacy, persistence, and academic performance [1-7]. It would not be precipitous to say that self-regulation of learning is based on a framework of bidirectional relationships which mediate between personal and contextual variables.

In this context, over recent years there has been particular interest in the study of the relationship between self-regulation and variables such as student well-being, satisfaction, and school engagement. Despite self-regulation in other fields such as healthcare having been shown to influence individuals' well-being [8-13], this has not been so solidly established in the educational arena. The present study centers on whether self-regulation skills in the educational context are associated with student well-being. Promoting student well-being is part of teaching, and we would expect learners' self-regulatory skills to be associated with their well-being and academic satisfaction.

The evaluation of well-being is complex due to the multidimensional nature of the construct, as well as the dispersion in the measures and overlap between well-being and the quality-of-life construct. In the literature, there is a clear differentiation between subjective well-being-happiness-and psychological well-being. Whereas subjective well-being includes cognitive measures about satisfaction with life and measures of the experience of positive and negative affects [14,15], psychological well-being is seen as a multidimensional concept that usually distinguishes six factors (self-acceptance, positive relationships with others, autonomy, mastery of the environment, purpose in life, and personal growth $[16,17]$ ). Widening the focus from well-being includes the construct of quality of life [18], which describes a person's physical, psychological, mental, social, and functional well-being in terms of interpersonal relationships, social inclusion, personal development, material well-being, self-determination, and both legal and human rights [19]. 
Considering the objective of this research, we must not lose sight of the fact that the self-regulation of learning is also understood as a complex multidimensional construct that we approach by considering the use of learning strategies and the skills and abilities needed to monitor and organize one's own learning, manage time, maintain attention, reduce anxiety, delay gratification, and persist in the pursuit of set goals [20]. In this regard, it is common to find measures of self-regulation in terms of the use of self-regulation strategies, coping strategies and resources, measures of executive processes that underlie the self-regulatory process, and measures in terms of self-regulatory deficits [21-23].

Research on these two constructs is extensive and prolific, however, to our knowledge, no meta-analytic or systematic review studies have been conducted to explore the interaction between these two constructs in the educational context; therefore, we believe this topic deserves further investigation.

We performed a systematic review in order to specify how and to what extent selfregulation of learning has been linked to student well-being over the last ten years. Given the empirical evidence of the relationship between well-being and various measures associated with self-regulation such as autonomy or autonomous regulation [24,25], setting goals [26-29], self-efficacy, academic performance [30,31], and self-control [32,33], it is worth asking how closely self-regulation is linked to-and how much does it affect-student well-being [34-36]. With this objective, we reviewed in accordance with the protocol for systematic reviews or meta-analyses from the PRISMA declaration for systematic examination [37].

\section{Method}

\subsection{Eligibility Criteria}

The following conditions were applied to select articles found in databases. First, studies included were published between 2010 and February 2020, either in Spanish or English language. Only articles with the full text available from researchers or research groups located in Europe, North America, South America and Oceania were included. In addition to language, country of publication and time, other inclusion/exclusion criteria were taken into account. All research articles included (excluding qualitative, theoretical, and meta-analytical works) focused on an educational context. The samples' studies had to consist of students and, finally, the measures and analyses had to prove a certain relationship between them (positive, negative or null relationship), excluding exploratory studies that do not provide information on the interaction between variables.

\subsection{Search Strategy}

The search strategy comprised an initial systematic review of articles published in various databases such as MEDLINE, Academic Search, PsycINFO, SCOPUS, WOS, SCIELO and REDALYC. The aim of the search was to find papers that explored self-regulation in the educational context and related it to academic achievement and student well-being.

The objective was to improve the results over time and produce an overview that would help us reach conclusions about various aspects of research on self-regulation over the last ten years. The search terms related to self-regulation used in the initial search of the databases are: Self-Regulation, Regulation, Self-Regulation Learning, Cognition, Metacognition, Self-Regulated Strategies and Executive functions. On the other hand, the well-being related search terms used in the initial search of the databases are Well-Being, Quality of life, Subjective well-being, Wellness, Welfare, Health and Happiness.

\subsection{Types of Studies, Participants and Outcome Measures}

For this review, we selected studies that examined the relationship between selfregulation of learning and well-being in the educational field, as our aim was to determine whether there was a relationship between these two theoretical constructs. This meant that all of the studies we examined needed to look at student self-regulation (whether directly or indirectly) where the outcome variable was academic well-being (subjective or 
psychological) or quality of life. Studies which did not have direct or indirect measures of self-regulation and studies using theoretical, qualitative or meta-analytical methodologies were excluded.

In terms of participants, the review included studies covering a range of student samples, from early childhood and primary education to college, university, or equivalent levels. Age, race, gender, socioeconomic status, and other sociodemographic information were not subject to limitation. Studies in which the participants were exclusively adults (not students), parents or teachers were excluded.

There are two types of well-being in the conceptual framework we followed, subjective and psychological. Both have multiple dimensions making it difficult to find a single definition that completely frames the concept. Our review covered studies that understood well-being as having good mental health, feeling highly satisfied with life/the academic context, having a sense of meaning or purpose, the ability to manage stress, having a positive or negative affect, having self-esteem, being optimistic and empathetic, and perceiving social support, among others.

\subsection{Selection Process}

The process of selecting the articles to include in the study followed various phases (see Figure 1 for a flow diagram outlining the process). The first phase was to identify the papers in the databases noted above using various combinations of search terms and time parameters.

Following that, the pre-selected articles were screened to eliminate duplicates, articles which appeared incomplete, and articles that were not in English or Spanish. After that reduction, we began the eligibility process, in which each paper was reviewed in detail to refine and specify the search.

Papers were eligible for review if they specifically explored the relationship between self-regulation and well-being in educational contexts. They were excluded if self-regulation was not examined, the study was not in an educational context, the sample was not students, the study did not have quantitative results, or the study had not been done in the stipulated locations.

\subsection{Meta-Analysis}

To perform the meta-analysis, we used the effect size measurements in each study because they indicate the magnitude of the effect produced in the variables. Effect size is a statistical index that measures the magnitude of the experimental effect in each study and is not affected by the sample size, unlike statistical significance tests [38]. There are different families of effect size indices whose proper application depends on the purpose of the study, the design used, and the types of variables measured [39-41]. The most frequently used effect size indexes in meta-analyses are as follows [42,43]:

- The " $d$ " family, particularly indicated for studies applying designs with two groups with the result measured continuously. It consists in calculating the difference between the means of the two groups and, optionally, dividing that by the joint standard deviation of both groups.

- The " $\mathrm{r}$ " family, specially indicated for correlational studies, is based on obtaining a correlation coefficient.

- The risk index family, indicated for studies with two groups in which the outcome variable is dichotomous (e.g., pass vs. fail, improvement vs. no improvement).

The nature of the selected studies made it impossible to statistically combine the results from each study. We decided to continue the review qualitatively, making a systematic review of the selected articles. Throughout the review, the results are provided in detail in terms of effect size in order to demonstrate the relationships between the variables described. 

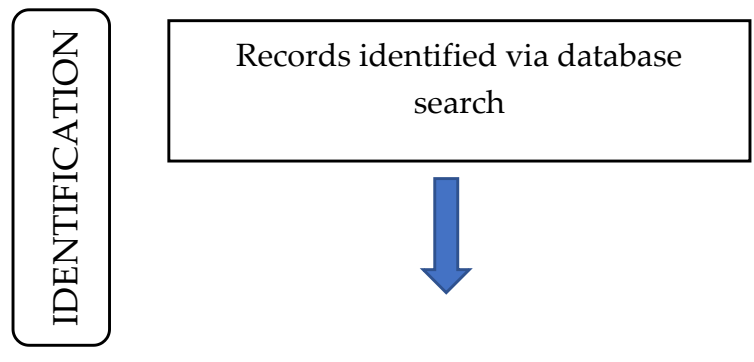

Additional Records identified via other sources $(n=4)$

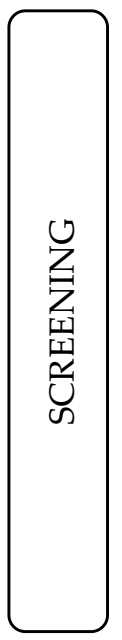

Records following removal of duplicates, not full text, and not English or Spanish $(\mathrm{n}=1756)$
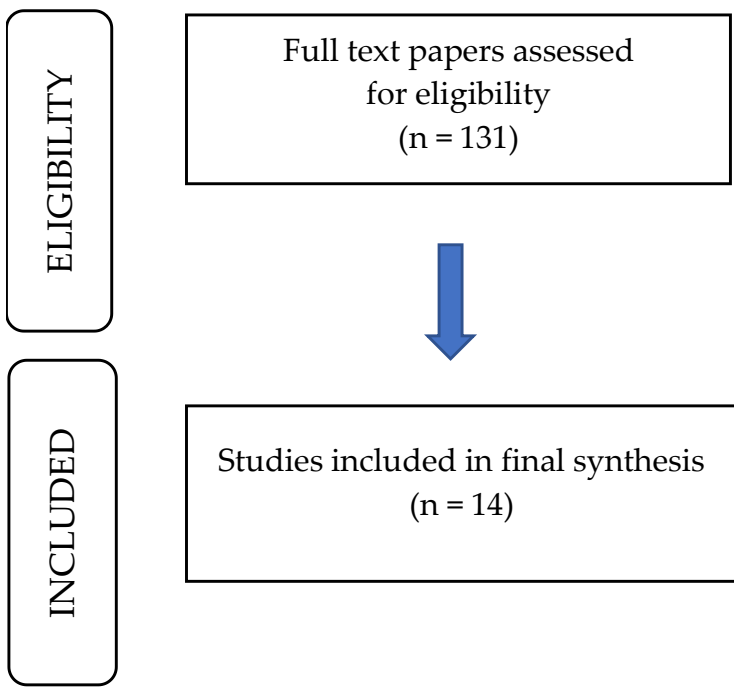

Full text papers excluded, with reasons $(n=117)$

- Not educational context $(\mathrm{n}=86)$

- Not SRL in Wellbeing $(\mathrm{n}=15)$

- Not in students $(n=3)$

- Not in Europe, America or

Studies included in final synthesis $(\mathrm{n}=14)$ Oceania $(n=2)$

- Theoretical study $(\mathrm{n}=4)$

- Meta-analysis study ( $n=6)$

- Qualitative study $(\mathrm{n}=1)$

Figure 1. Flow diagram of the process for selecting studies to include in the review.

\section{Findings}

\subsection{Description of Included Papers}

The initial search in the databases gave 2252 results. We selected 131 full-text articles to review against the eligibility criteria and once that evaluation was complete, a total of 14 articles were included in this review. At the end of this article in Appendix A, the articles included are listed with information about the aims of the study, the measures used, the results, and the characteristics of each article $(n=14)$. Appendix B lists the articles which were excluded and the reasons for the exclusion $(n=114)$. In Appendix C, Table A3 contains the impact factors to assess the quality of the selected publications. 


\subsection{Methodology of Included Papers}

The majority of the studies were cross-sectional [43-51], followed by prospective [52-55] and experimental/intervention [56].

The measures used to evaluate self-regulation were essentially self-reported $[43,44,49,50,52,55]$ and/or reported by others $[48,54,56]$. Only the study by Woodkward et al. [51] used measures of self-regulating behavior through direct observation and information from others.

\subsection{Evaluation of Self-Regulation}

Self-regulation is a complex construct with a broad history of research which, while enriching educational practice, can make it hard to give the construct a clear identity and differentiate it from other associated constructs. In fact, faced with the complexity of combining the evaluation criteria of the construct of self-regulation in educational contexts, we decided to perform a qualitative review and dispense with meta-analytical processes. In order to give a sufficiently analytical picture, below we aim to differentiate between studies which assessed the use of strategies in different phases or areas of self-regulation, studies focused on the assessment of self-regulation deficits, and studies which evaluated executive processes.

Approaching self-regulation based on strategy use allows us to see an association with phases and areas of the process [57]. Bryce et al. [43] used the Intentional Self-Regulation Questionnaire [58] to evaluate students' behavioral hope, collecting information related to planning in terms of goal selection and the optimization of resources. They also collected executive information about flexibility in using alternative means to stay engaged with the task at hand (compensation).

Litalien et al. [50] used a combination of measures taken from Emmons [59], Little [60] and Sheldon and Elliot [61] and, using the SDT framework [62], evaluated personal goals and the relative autonomy index for each personal goal. These measures fall within the initial phase of the self-regulation process as they refer to the selection and identification of personal goals.

Fomina et al. [53] used Morosanova's Self-Regulation Profile Questionnaire [63] to evaluate a series of aspects related to planning, such as goal setting, modeling significant conditions, and programing activity, they also addressed supervision of the process, evaluating results, flexibility, independence, and responsibility. Similarly, García et al. [54] used the Regulatory Mode Questionnaire [64] to assess self-regulation, differentiating between aspects related to learner planning and availability-assessment—and aspects related to the implementation of learning processes-locomotion. Locomotion is understood as all of those characteristics and actions that allow one to advance towards goals, whereas assessment is an initial phase of the process which allows the learner to reflect, compare, and assess the potential results of implementation. Guilmette et al. [47] used a selection of items adapted from Wrosch et al. [65] to study the capacity to manage goals, measuring variables such as persistence, assertiveness, and consistency in doing tasks, and the tendency to make positive reappraisals.

Coping during the execution phase was also assessed by Cahua et al. [44] using the Adolescent Coping Scale [66], which differentiates between three coping types: productive coping, aimed at resolving problems, staying optimistic, and having a socially connected attitude; a relationship-oriented style focused on resolving problems through the support of others-seeking social support, seeking spiritual support, seeking professional help, social action; and an unproductive coping style, which combines the use of avoidant strategies-worry, investing in close friends, wishful thinking, ignoring the problem, seeking to belong, reducing stress, not coping, keeping it to oneself, and self-blame. On similar lines, Elliot et al. [52] used the Coping Responses Inventory [67] to evaluate Avoidance coping in two subscales, one of cognitive avoidance-avoiding thinking realistically about problems - and one of behavioral avoidance, which refers to strategies such as emotional discharge, aimed at reducing tension by expressing negative feelings rather than addressing the problem. 
Within this framework of more emotional management, Gaspar et al. [46] created their own scale based on the framework of the International Resilience Research Project [68]. They used a measure of resilience to assess executive skills for managing resources for a task or in adversity depending on the source: provided external support, developed inner strengths, and acquired interpersonal and problem-solving skills.

Lázaro-Visa et al. [49] assessed both cognitive strategies and the management of negative emotions in their study. They used Social Attitudes and Cognitive Strategies [69] to incorporate social attitudes and problem-solving strategies-observation and retention of relevant social information, search for alternative solutions for solving conflicts, anticipation, reflection about consequences, and selection of means. They also used the Trait Meta Mood Scale [70] to assess the ability to repair negative emotional states. Woodward et al. [51] also used a measure of emotional self-regulation, using the Emotion Regulation Checklist [71]. Perry et al. [55] used the Motivated Strategies for Learning Questionnaire [72] to assess self-regulation. This subscale assesses metacognitive learning strategies and effort management. In the same study, they used the Africultural Coping System Inventory-Youth Version [73] to evaluate different types of coping skills (emotional debriefing, spiritually centered coping, maintaining harmony and communalism).

Howard et al. [54], Kornienko et al. [48], and Woodward et al. [51] chose to assess self-regulation considering the difficulties students face in regulating their learning. Howard et al. [54] analyzed information provided by parents, teachers, and students in interviews using factors developed by Moffitt et al. [32]. They assessed difficulties in controlling and sustaining attention, emotions, and controlling behavior-such as being restless or overactive.

Kornienko et al. [48] used the Strengths and Difficulties Questionnaire [74] to identify emotional difficulties and peer problems (internalizing problems), and behavioral problems and hyperactivity (externalizing problems).

Finally, Aadland et al. [56], Kornienko et al. [48] and Woodward et al. [51] assessed self-regulation looking at basic cognitive processes or executive functions. In addition to using a measure of behavioral self-regulation in a classroom setting reported by teachers [75], Aadland et al. [56] assessed inhibition, working memory, and cognitive flexibility. Kornienko et al. [48] used The Effortful Control Scale of the Temperament in Middle Childhood Questionnaire [76,77] to assess activation control, attention focusing, inhibitory control, low intensity pleasure, and perceptual sensitivity. Woodward et al. [51] evaluated cognitive functioning through direct observation of the subject, performance of activities, and using the Bayley Scales of Infant Development-Second Edition (BSID-II) [78].

\subsection{Evaluation of Well-Being}

The measures of well-being in the studies included in our review shared certain characteristics that, as was the case with self-regulation, led us to drop the meta-analytical analysis and obliged us to choose a more qualitative analytical approach. The evaluation of student well-being was addressed considering subjective well-being, but also in terms of psychological well-being and within a wider construct of Quality of Life. Some authors used other measures to report student well-being.

There was a clear predominance of studies measuring solely subjective well-being [50,52] compared to those that measured solely psychological well-being [53]. Two studies included measures of both types of well-being [44,45]. More specifically, Garcia et al. [45] evaluated the two dimensions making up subjective well-being (positive/negative affect and satisfaction with life) and the six dimensions making up psychological well-being (autonomy, environmental mastery, personal growth, positive relations with others, purpose in life, and self-acceptance). They used the Positive Affect/Negative Affect Schedule (PANAS) [79] to measure positive/negative affect. This instrument assesses the affective component of subjective well-being by asking the student the extent to which they have experienced positive emotions (interest, satisfaction, happiness, vitality ... ) or negative emotions (fear, nervousness, guilt, anxiety ... ) in recent weeks. Satisfaction with life was 
assessed using the Temporal Satisfaction with Life Scale [80] which assesses the cognitive component of subjective well-being measuring satisfaction with life in the past, present, and future. Psychological well-being was assessed using Ryff's short test [81], a single scale that measures the six dimensions making up this type of well-being.

Cahua et al. [44] specifically measured satisfaction with the life dimension of subjective well-being and the purpose in the life dimension of psychological well-being. They used the Purpose in Life Test [82]. Through a series of cases, they explored people's perceptions of the meaning of life, motives and reasons to live, their evaluations of their lives, their perceptions of their own day-to-day lives, objectives linked to specific life actions, and their perceived personal responsibility for their own lives. In terms of satisfaction with life, the study used The Satisfaction with Life Scale [83] which measures people's perceptions about whether life is close to their ideal, whether they would change anything if they could live their life over, if they feel that the conditions of their life are excellent, whether they have everything they feel to be important in their life, and whether they are satisfied with their life generally.

Two studies assessed subjective well-being by simultaneously measuring its two dimensions, positive/negative affect and satisfaction with life [15,83]. Elliot et al. [52] created an index of subjective well-being (SWB) which addressed positive and negative affect measured using the Short Positive Affect/Negative Affect Scale [84], and life satisfaction via The Satisfaction With Life Scale [83]. Litalien et al. [50] measured satisfaction with life using the "satisfaction with present life" subscale from the Temporal Satisfaction with Life Scale [80]. This scale asks questions related to the extent to which a person (talking about the present) would change anything in their life, whether they had everything they wished to have, and whether they were satisfied with their life. The same study also assessed positive and negative affect using the Positive and Negative Affect Schedule (PANAS) [79], which was also used by Garcia et al. [45] in the study in this review.

Two studies focused on evaluating subjective well-being using only the satisfaction with life dimension. Kornienko et al. [48] used the Russian version of the Students' Life Satisfaction Scale [85]. This scale measures students' satisfaction with life by their agreement or otherwise with certain statements, such as whether they felt their lives to be better than others', about the things in their life they would change, and whether they had a good life. Lazaro-Vaisa et al. [49] measured satisfaction with life using the Personal Well-Being Index [86]. This instrument is a general, abstract evaluation of satisfaction with certain aspects of life such as health, standard of living, life achievements, groups subjects are members of, future security, relationships with others, spirituality, and religion.

The most commonly assessed dimension within subjective well-being was positive and negative affect, with four studies. Guilmette et al. [47] measured the full "Positive and negative affect" dimension using the Positive and Negative Affect Schedule (PANAS) [79] described previously, in relation to other studies reviewed $[45,50]$.

We did find other authors who had evaluated the dimension of positive/negative affect by measuring specific negative emotions such as anxiety and stress, although they focused exclusively on the negative affect part of this dimension. For example, Bryce et al. [43] used the Adolescent Stress Questionnaire [87] to measure student stress. Students reported their feelings of stress related to their peers and teachers within a school environment and about their feelings of stress about their future. The same authors used two items from the Generalized Anxiety Disorder scale [88] to measure students' feelings of anxiety. This instrument aims to gather information related to whether students feel restless, nervous, worried, if they feel muscular tension, or if they have problems sleeping.

Howard et al. [54] chose to carry out face-to-face interviews with students' parents or guardians. In the interview they asked about students' mental health concerning ongoing stress or anxiety in the young people's lives. Finally, Woodward et al. [51] assessed the presence of anxiety in students via the Development and Well-being Assessment (DAWBA) [89] within interviews with parents in order to understand the impact of various disorders, including anxiety disorder. 
We found a single study that solely assessed students' psychological well-being. Fomina et al. [53] used a Russian adaptation of the Well-Being Manifestation Measure Scale [90] to evaluate specific dimensions of psychological well-being. They measured the extent to which participants had experienced certain states related to mastery of the environment (control over events and control over oneself), purpose in life (enjoying each moment in life and finding it exciting), positive relations with others (social participation), self-acceptance (through understanding self-esteem), and personal growth (finding a balance between the different aspects of one's life).

Addland et al. [56] and Gaspar et al. [46] used the long and short versions, respectively, of the Kidscreen Questionnaire [91] to evaluate the different dimensions of students quality of life. Addland et al. [56] reported students' physical well-being, psychological well-being, relationships with parents, autonomy, social support, and school atmosphere. Gaspar et al. [46] focused on perceived social support and the relationship with parents as indicators of student well-being. On similar lines, Perry et al. [55] assessed student well-being considering the students' perceptions of social support from parents, teachers, and peers. They used the Teacher Support Scale [92] to measure social support from teachers, which measures the extent to which students feel that their teachers care about them, have a positive regard for them, support them emotionally, and have high expectations for them. Perceptions of parental support were assessed using the Parental Career Behavior Checklist [93], which specifically measures whether the child feels that their parents try to understand their problems or are interested in their academic concerns. The final measure they used was via the Peers' Academic Aspirations and Support measure [94], assessing perceptions of social support from peers. This scale was created to assess the perceptions of support from peers for specific academic activities and school engagement.

\subsection{Executive Functions and Student Well-Being}

Although the study by Aadland et al. [56] suggested that there was no relationship between inhibition, working memory, cognitive flexibility and school-related well-being in fifth-grade schoolchildren, Kornienko et al. [48] found that the ability to focus attention had an impact on subjective well-being - satisfaction with life- $(\beta=0.28, p<0.001)$ and would reduce both emotional and/or peer-related problems $(\beta=-0.85, p<0.001)$ and behavioral problems $(\beta=-0.58, p<0.001)$ in $7-10$ year-old children. Inhibitory control also contributed to specifically limiting these latter externalizing problems $(\beta=-0.43, p<0.001)$.

\subsection{Self-Regulation Strategies and Student Well-Being}

In general, self-regulation of learning was positively linked to perceptions of support from parents $(\mathrm{r}=0.26, p<0.01)$, teachers $(\mathrm{r}=0.27, p<0.01)$, and even with satisfaction with peers $(\mathrm{r}=0.19, p<0.01)$ in students aged $13-19$ years old $(\mathrm{M}=15.71 ; \mathrm{SD}=1.24)$ [55].

Although only confidence, perceived self-efficacy, and expectations of success-cognitive hope-were found to be significant buffers for anxiety or future and interpersonal stress in high school (9th to 12th grade), Bryce et al. [43] found that goal selection could reduce future-oriented stress. Litalien et al. [50] reported that students in their final years in upper secondary school (Mage $=19.51 ; \mathrm{SD}=0.77$ ) who had more autonomous reasons to pursue their personal goals at the end of high school were more likely to report higher enjoyment of their lives and healthier affect two years later. Autonomous goal regulation, as part of the SDT framework (Deci \& Ryan, 2000) positively predicted later life satisfaction ( $\beta=0.10$, $p<0.01)$ and positive affect $(\beta=0.15, p<0.001)$, and negatively predicted negative affect $(\beta=-0.11, p<0.001)$.

Using a longitudinal design, Fomina et al. [53] found that the ability to create plans in the 4 th grade $($ Mage $=10.31, \mathrm{SD}=0.48)$ had a positive impact on mental balance $(\beta=0.60$; $p<0.01)$, sociability $(\beta=0.62 ; p<0.01)$, self-esteem $(\beta=0.60 ; p<0.01)$, and the control of self and events $(\beta=0.48 ; p<0.05)$ in the 5th grade (Mage $=10.62$; SD $=0.50)$. On similar lines, looking at high school pupils (Mage $=17.74 ; \mathrm{SD}=1.29$ ), Garcia et al. [45] found that activation, proactivity, and forward-striving — striving to achieve a goal—were 
positively linked to both subjective well-being $(\mathrm{r}=0.48 ; p<0.01)$ and psychological wellbeing ( $\mathrm{r}=0.58, p<0.01)$. Guilmette et al. [47] reported a correlation between determination in goals, consistency, coping with obstacles (persistence), and both positive affect ( $\mathrm{r}=0.50$, $p<0.01)$ and negative affect $(\mathrm{r}=-0.25, p<0.01)$ in university students $(\mathrm{M}=21.11 ; \mathrm{SD}=1.68)$.

Although better understanding is needed of how these cognitive-motivational aspects may moderate the relationship between experiences and well-being in achievement contexts, it seems that establishing one's own goals and commitment to achieving them contribute to students' well-being.

Fomina et al. [53] looked at students aged 10-12 $(\mathrm{M}=10.62 ; \mathrm{Sd}=0.50)$ and found a positive impact of the ability to manage their own achievements — evaluating results—on happiness $(\beta=0.45 ; p<0.05)$ and self-esteem $(\beta=0.43 ; p<0.05)$. However, with high school pupils (Mage $=17.74 ; \mathrm{SD}=1.29$ ) a tendency for strategic thinking and assessing different goals and pathways was negatively associated with subjective well-being [45]. From a sample of university students $(M=21.11$; $S D=1.68)$, Guilmette et al. [47] reported a positive correlation between positive reappraisals and positive affect $(\mathrm{r}=0.44, p<0.01)$ and a negative correlation with negative affect $(\mathrm{r}=-0.30, p<0.01)$. It is worth highlighting here the mediation analysis in this study which suggested that engagement with activities-determination in one's goals, consistency, and coping with obstacles (persistence)-contributed not only to limiting negative affect, but also reinforced the ability to see the positive side of negative events-positive reappraisal. The role of self-evaluation (rigorously reflecting on and evaluating different possibilities for achieving goals) on student well-being should address, for example, the level of achievement, expectations of success, and the competitiveness of the context, exploring the impact in different age ranges.

Lázaro-Visa et al. [49] reported that the ability to manage negative emotions $(\beta=0.11$, $p<0.01$ ), along with self-esteem, were explanatory self-regulatory factors of student satisfaction in 10- to 18-year-olds (Mage $=12.98$; SD $=1.78$ ) when other conditions and contextual variables were included in the regression models. Gaspar et al. [46] looked at a sample of Spanish and Portuguese students aged between 8 and 17 years old (Female: Mage = 9.8; $\mathrm{SD}=1.32$; Male: Mage $=10 ; \mathrm{SD}=1.53$ ) and found that, along with self-esteem and optimism, resilience was a personal variable explaining happiness and satisfaction with family, school, and peers in children and adolescents with cognitive and developmental difficulties $(\beta=0.124, p<0.01)$. These results are particularly interesting as children and adolescents with SEN are an at-risk group in terms of subjective well-being (Bullinger, Schmidt, Petersen \& The Disabkids-Group, 2002).

Cahua et al. [44] found coping styles to be explanatory factors of purposes in life and satisfaction in adolescents aged 14 to $18(\mathrm{M}=15.47 ; \mathrm{SD}=0.80)$. The study by Perry et al. [55], with a sample of adolescents $(M=15.71 ; S D=1.24)$, concluded that satisfaction with others was correlated with the use of coping skills, such as attempting to manage situations through self-expression and creativity-emotional debriefing $-(\mathrm{r}=0.19, p<0.01$ and $r=0.19, p<0.01$, for satisfaction with teachers and parents, respectively), through faith or religion-spiritually centered coping $(r=0.21, p<0.01$ and $r=0.20, p<0.01$, for satisfaction with teachers and parents, respectively), through relationships with others $(\mathrm{r}=0.26, p<0.01$ and $r=0.25, p<0.01$, for satisfaction with teachers and parents, respectively), or maintaining harmony $(\mathrm{r}=0.23, p<0.01$ and $\mathrm{r}=0.22, p<0.01$, for satisfaction with teachers and parents, respectively). In contrast, Elliot et al. [52] found that avoidance coping, both cognitive and behavioral, reduced undergraduates' psychological well-being. Avoiding thinking realistically about problems $(\beta=-0.14 ; p<0.05)$ and reducing tension, expressing negative feelings rather than dealing with the problem $(\beta=-0.19 ; p<0.01)$ reduced subjective well-being in a sample of undergraduates with a mean age of 19.95, even controlling for social desirability, basic traits, and general motivational disposition. One important task for the future will be to explore the differing impact of approach and avoidance regulation. Developing models that specifically incorporate reactivity and proactivity seems to be essential as variables related to individuals' well-being come into play in the explanations of educational success. 


\subsection{Self-Regulation Deficits and Student Well-Being}

Applying a longitudinal approach, Woodward et al. [51] concluded that poorer early regulatory abilities were a significant predictor of a range of later mental health disorders. More specifically, behavioral and emotional self-regulation in children at 2 years old was an important predictor of $\operatorname{ADHD}(\beta=-0.16, p<0.01)$, conduct disorder $(\beta=-0.14, p<0.05)$, and anxiety disorders $(\beta=-0.14, p<0.01)$ at 9 years old. In addition to doubling the risk of self-harming ideation and behavior and suicidal ideation, Howard et al. [54] suggested that problems of self-regulation reported by parents and teachers- the extent to which children can control and sustain attention, control their behavior, and their emotions-in $4-5$ year-olds and 6-7 year-olds was associated with a 2-times increase in conditions of depression and/or anxiety in adolescence (OR: 1.73, $p<0.01$, CI 95\% [1.51-1.94] and OR: $1.70, p<0.01$, CI 95\% [1.48-1.91], respectively).

\section{Discussion}

This systematic review summarized the last ten years of research into the association between self-regulation and well-being in the educational setting, covering a variety of age ranges. A total of 14 articles were considered which explored the issue from selfregulation skills and executive functions in early ages to the use of self-regulation strategies in secondary and pre-university students.

The first general finding the review produced was the recognition of the problem of combining the criteria for evaluating the construct of self-regulation in the educational arena. The multiplicity of approaches and the multidimensional nature of the construct made it impossible to combine specific findings for a meta-analytical exploration. Although the broad empirical evidence that exists enriches educational practice, as we mentioned previously, it also makes it very hard to give self-regulation a single identity or differentiate it from other constructs it is linked to, in our case it also removed the possibility of achieving generalizable, consensus knowledge by not allowing us to statistically combine the research results.

The qualitative, systematic analysis of the articles in this review showed that both some executive functions and some self-regulation strategies employed in the learning process, as well as some self-regulation deficits, are significantly associated with different measures of student well-being.

The relationship between executive functions and student well-being revolves around the ability to focus attention and inhibitory control. The results suggest that students who can focus their attention demonstrate greater satisfaction with life and fewer emotional or behavioral problems, and fewer problems in peer relationships. Along similar lines, those who exhibit greater inhibitory control demonstrate fewer behavioral problems [48,56]. This may be due to the relationship between effort control (focusing attention and inhibitory control) and the self-regulation of learning [95], as well as the relationship with academic performance $[96,97]$. Based on the evidence, it seems logical that a student with good indices of effort control would better self-regulate their learning and achieve better results, increasing their satisfaction with life. Similarly, self-regulation of the learning process, which also refers to the ability to regulate emotion and behavior during engagement with academic activity, would also result in reduced emotional and behavioral problems as well as resulting in the use of adaptive strategies to express and resolve problems.

There was also evidence that the use of different learning self-regulation strategies was closely and significantly related to student well-being. We found that goal selection would reduce future-oriented stress, but not only that, if this goal selection was autonomous, it could predict future satisfaction with life, positive affect, and prevent negative affect $[43,50]$. On similar lines, other authors suggested that being proactive and striving to achieve goals that are set were linked with better subjective and psychological well-being. Determination in seeking set goals, the ability to be consistent in the tasks related to them, and persistence in the pursuit of achieving them have positive effects on positive affect and reduce negative affect $[45,47]$. In parallel to goal-setting, we found that the ability to create plans impacts 
student well-being as it improves mental balance, sociability, and control of self and events [53].

Looking at the supervision and assessment phases of the self-regulation of the learning process in this review, it showed that strategies such as evaluating results had positive impacts on happiness and self-esteem at the beginning of primary education, whereas in secondary school, strategies related to the assessment phase such as strategic thinking, and assessing different goals and pathways were negatively linked to student well-being. However, when students reached university level, these same strategies were positively related to positive affect and negatively related to negative affect $[45,47,53]$. This may be because at the university level there is more determination with goals, as well as greater consistency and persistence, which may contribute to limiting the negative effects, enhancing the ability to see the positive side of negative events.

Another finding from this review revolves around the relationship between managing negative emotions and student well-being and satisfaction [49]. In this regard, resilience may be considered an explanatory personal variable of happiness and satisfaction with family, school, and peers in children and adolescents with cognitive and developmental difficulties [46]. The informative study by Gaspar et al., (2016) showed that when social and personal variables were included, the association between the condition of being a student with SEN and well-being was no longer statistically significant, which may suggest that personal factors such as resilience are protective factors for well-being in these populations.

Coping strategies and styles were also seen to be explanatory factors for purpose in life and satisfaction with life [44]. The types of strategies people used to cope with or manage situations had an impact on one or more of the dimensions of well-being [55]. Students who used strategies of emotional debriefing, spiritually centered coping, or maintaining harmony had higher levels of satisfaction with teachers and parents, bearing in mind the correlation between these two measures. In turn, strategies such as avoidance coping (both cognitive and behavioral) reduced student psychological well-being [52].

Finally, considering the relationship between self-regulation deficits and student well-being, we found that poorer early regulatory abilities were a significant predictor of a range of later mental health disorders, conduct disorders, and anxiety disorders [51]. Similarly, problems with maintaining attention and controlling emotions or behavior in early childhood also had an impact on the likelihood of suffering from anxiety or depression in adolescence [54]. The capacity for attention, as well as the ability to manage one's behavior and emotions in early childhood may be key in minimizing a broad range of problems linked to health and well-being in adolescence.

\section{Conclusions}

We believe that some general implications can be drawn from this article. The first of them refers to the need to reach some level of consensus in the scientific community intending to give self-regulation a clear identity based on clearer evaluation criteria in the educational context. This will only be achieved with a continual interaction between and within disciplines that will allow rigorous modification when it comes to defining or conceptualizing the construct. In this regard, there should be a continued exploration of the role of executive functions as they underlie the process of self-regulation of learning in students.

Secondly, both for improving the different dimensions of well-being, as well as to prevent future problems, there needs to be explicit work on setting academic goals, support for goal selection and planning, as well as consistency and persistence in pursuit of those goals. It would also be useful to encourage students to play a greater role in the most evaluative phase of the self-regulatory process, and there should be intervention in the self-evaluation and monitoring of the process and results as that could have a positive impact on the development of adaptive attributional patterns and coping styles.

It is important to highlight the need to strengthen interventions into students' emotional management or self-regulation, especially in the preservation of self-esteem, focusing 
specifically on resilience, which is a protective factor in both typical populations and those with special educational needs.

Finally, we must re-emphasize the opportunity to promote self-regulation abilities at early ages, as it is a preventive factor for future well-being and against mental disorders-anxiety and depression—and behavioral disorders—-self-harm and suicidal ideation—in adolescence.

\section{Limitation}

This study has some limitations. Firstly, the reliability of some of the instruments used for evaluating self-regulation was unknown, as most were adaptations or translations from an original. It is also worth noting that the close context of the classroom and teaching styles were not considered, nor were gender differences explored as most of the items were assessed by age. In addition, various articles offered a range of correlation indices without specifically indicating the numerical relationship between the variables, and some articles did not provide the mean or standard deviation for the age of the sample.

Author Contributions: Conceptualization, S.R. and I.P.; methodology, R.G.-S.; validation, S.R., T.V. and I.P.; S.R. and R.G.-S.; formal analysis; R.G.-S. and F.M.D.-F.; investigation; R.G.-S., T.V. and F.M.D.-F.; resources; S.R.; data curation; R.G.-S. and S.R.; writing-original draft preparation, I.P. and T.V.; writing-review and editing; F.M.D.-F.; visualization; S.R.; supervision and project administration, R.G.-S.; funding acquisition. All authors have read and agreed to the published version of the manuscript.

Funding: This research was funded by Deputación Provincial de A Coruña through The Research Grants Program 2021 in social and legal sciences. Grant number: 2021000025393, FPI Program of the Ministry of Science, Innovation and Universities (PRE2018-084938) and Xunta de Galicia (Consellería de Cultura, Educación y Universidad) under a predoctoral fellowship [ED481A 2021/351].

Institutional Review Board Statement: Not applicable.

Informed Consent Statement: Not applicable.

Data Availability Statement: Not applicable.

Conflicts of Interest: The authors declare no conflict of interest. 


\section{Appendix A}

Table A1. Systematic review table (alphabetical according to first author)

\begin{tabular}{|c|c|c|c|c|c|c|}
\hline $\mathbf{N}$ & Author & Aim (s) of Study & Self-Regulatory Measure & Measure of Well-Being & $\begin{array}{c}\text { Participants and Method } \\
\text { Design }\end{array}$ & Findings \\
\hline 1 & Aadland et al. [56] & $\begin{array}{l}\text { To understand the mediating effects of } \\
\text { executive control, behavioral } \\
\text { self-regulation and school well-being } \\
\text { on the relationship between physical } \\
\text { activity and mathematics } \\
\text { performance. }\end{array}$ & $\begin{array}{l}\text { Behavioral Self-Regulation in } \\
\text { classroom } \\
\text { Executive function: Inhibition, } \\
\text { Working memory and Cognitive } \\
\text { flexibility }\end{array}$ & $\begin{array}{l}\text { Quality of life: Physical } \\
\text { well-being, Psychological } \\
\text { well-being, Relationship } \\
\text { with others, Autonomy and } \\
\text { Social support. }\end{array}$ & $\begin{array}{l}\mathrm{N}=1020 . \\
\text { Gender: } 458 \mathrm{~F}, 562 \mathrm{M} \\
\mathrm{M}_{\text {age: }} 10.2 \\
\text { Desing: Intervention }\end{array}$ & $\begin{array}{l}\text { No relationship between inhibition, } \\
\text { working memory and cognitive flexibility } \\
\text { with school related well-being }\end{array}$ \\
\hline 2 & Bryce et al. [43] & $\begin{array}{l}\text { To examine the contributions of } \\
\text { cognitive and behavioral hope to } \\
\text { academic functioning and well-being. }\end{array}$ & $\begin{array}{l}\text { Behavioral hope: Goal Selection } \\
\text { and optimization } \\
\text { Cognitive hope: compensation }\end{array}$ & $\begin{array}{l}\text { Subjective well-being: } \\
\text { Positive and negative affect } \\
\text { (Stress and anxiety). }\end{array}$ & $\begin{array}{l}\mathrm{N}=643 \\
\text { Gender: } 52.4 \% \mathrm{~F} \\
\text { Mage: No data } \\
\text { Desing: Cross-sectional }\end{array}$ & $\begin{array}{l}\text { Goal selection could contribute to } \\
\text { reducing future-oriented stress. }\end{array}$ \\
\hline 3 & Cahua et al. [44] & $\begin{array}{l}\text { Testing an explanatory model and } \\
\text { proposing a predictive model of the } \\
\text { meaning of life in adolescents in } \\
\text { public educational institutions. }\end{array}$ & $\begin{array}{l}\text { Coping in the executive phase: } \\
\text { Productive coping } \\
\text { (problem-solving with optimism), } \\
\text { Relationship-oriented style } \\
\text { (solving problems through the } \\
\text { support of others) and } \\
\text { Unproductive style-avoidant } \\
\text { strategies }\end{array}$ & $\begin{array}{l}\text { Psychological Wellness: } \\
\text { Life Purpose. } \\
\text { Subjective Well-Being: } \\
\text { Satisfaction with life }\end{array}$ & $\begin{array}{l}\mathrm{N}=872 \\
\text { Gender: } 46.9 \% \mathrm{M}, 53.1 \% \mathrm{~F} \\
\mathrm{M}_{\text {age }}: \mathrm{M}=15.47, \mathrm{SD}=0.80 \\
\text { Desing: Cross-sectional }\end{array}$ & $\begin{array}{l}\text { Coping styles as explanatory factors of life } \\
\text { purposes and satisfaction among } \\
\text { adolescents. }\end{array}$ \\
\hline 4 & Elliot et al. [52] & $\begin{array}{l}\text { To examine stressors and avoidance } \\
\text { coping as mediators in the } \\
\text { longitudinal relationship between goal } \\
\text { avoidance and life satisfaction. }\end{array}$ & $\begin{array}{l}\text { Avoidance coping. } \\
\text { - Cognitive avoidance (avoidance } \\
\text { of realistic thinking about } \\
\text { problems). } \\
\text { - Behavioral avoidance } \\
\text { (emotional discharge). }\end{array}$ & $\begin{array}{l}\text { Subjective Well-being } \\
\text { Positive affect, negative } \\
\text { affect and life satisfaction. }\end{array}$ & $\begin{array}{l}N=159 \\
\text { Gender: } 56 \mathrm{M}, 103 \mathrm{~F} \\
\text { Mage: } 19.95 \\
\text { Desing: Longitudinal }\end{array}$ & $\begin{array}{l}\text { - Avoid thinking realistically about } \\
\text { problems reduce subjective well-being } \\
(\beta=-0.14 ; p<0.05) \\
\text { - Expressing negative feelings benefits } \\
\text { subjective well-being }(\beta=-0.19 ; p<0.01)\end{array}$ \\
\hline 5 & Fomina et al. [53] & $\begin{array}{l}\text { To determine whether self-regulation } \\
\text { skills are an important resource for the } \\
\text { psychological well-being of } \\
\text { schoolchildren. }\end{array}$ & $\begin{array}{l}\text { Planning: Planning the goals, } \\
\text { Modeling significant } \\
\text { preconditions, Programming } \\
\text { activity } \\
\text { Supervision of the process: } \\
\text { Evaluating results, Flexibility, } \\
\text { Independence and Responsibility }\end{array}$ & $\begin{array}{l}\text { Psychological Well- being: } \\
\text { Mastery of the environment, } \\
\text { Purpose in life, Positive } \\
\text { relationships with others } \\
\text { and Personal growth }\end{array}$ & $\begin{array}{l}\mathrm{N}=293 \\
\text { Gender: } 48 \% \mathrm{M}, 52 \% \mathrm{~F} \\
\mathrm{M}_{\text {age }}(\mathrm{M}=10.62, \mathrm{SD}=0.50) . \\
\text { Desing: Longitudinal }\end{array}$ & $\begin{array}{l}\text { - Ability to elaborate plans-mental } \\
\text { balance }(\beta=0.60 ; p<0.01) \text {, sociability } \\
(\beta=0.62 ; p<0.01) \text {, self-esteem }(\beta=0.60 ; \\
p<0.01) \text { and on the control of self and } \\
\text { events }(\beta=0.48 ; p<0.05) \\
\text { - Evaluating results- happiness }(\beta=0.45 ; \\
p<0.05) \text { and self-esteem ( } \beta=0.43 ; \\
p<0.05)\end{array}$ \\
\hline
\end{tabular}


Table A1. Cont.

\begin{tabular}{|c|c|c|c|c|c|c|}
\hline $\mathbf{N}$ & Author & Aim (s) of Study & Self-Regulatory Measure & Measure of Well-Being & $\begin{array}{c}\text { Participants and Method } \\
\text { Design }\end{array}$ & Findings \\
\hline 6 & García et al. [45] & $\begin{array}{l}\text { To find out whether self-regulation, } \\
\text { well-being and exercise behavior have } \\
\text { essential roles in influencing academic } \\
\text { performance. essential roles in } \\
\text { influencing academic performance. }\end{array}$ & $\begin{array}{l}\text { Learning readiness and planning: } \\
\text { Assessment } \\
\text { Aspects related to the } \\
\text { implementation of learning } \\
\text { processes: } \\
\text { Locomotion }\end{array}$ & $\begin{array}{l}\text { Subjective well-being: } \\
\text { positive and negative affect } \\
\text { and temporary satisfaction } \\
\text { with life. } \\
\text { Psychological well-being: } \\
\text { autonomy, mastery of the } \\
\text { environment, personal } \\
\text { growth, etc. }\end{array}$ & $\begin{array}{l}\mathrm{N}=160 \\
\text { Gender: } 111 \mathrm{M}, 49 \mathrm{~F} \\
\mathrm{M}_{\text {age }}: \mathrm{M}=17.74 \mathrm{SD}=1.29 \\
\text { Desing: Cross-sectional }\end{array}$ & $\begin{array}{l}\text { - Activation, proactivity and } \\
\text { forward-striving, Striving to achieve the } \\
\text { goal with subjective well-being }(\mathrm{r}=0.48 ; \\
p<0.01) \text { and psychological well-being } \\
(\mathrm{r}=0.58, p<0.01) \text {. } \\
\text { - Strategic thinking, assessing different } \\
\text { goals and pathways could be negatively } \\
\text { associated with subjective well-being. }\end{array}$ \\
\hline 8 & Guilmette et al. [47] & $\begin{array}{l}\text { To determine whether participation in } \\
\text { extracurricular activities is associated } \\
\text { with adaptive self-regulation of goals. }\end{array}$ & $\begin{array}{l}\text { Ability to self-regulate goals: } \\
\text { Persistence, Strength and } \\
\text { constancy and Positive } \\
\text { reappraisals. }\end{array}$ & $\begin{array}{l}\text { Subjective Well-Being: } \\
\text { Positive and negative affect }\end{array}$ & $\begin{array}{l}\mathrm{N}=401 \\
\text { Gender: } 23.2 \% \mathrm{M}, 76.8 \% \mathrm{~F} \\
\mathrm{M}_{\text {age }} \text { : No data } \\
\text { Desing: Cross-sectional }\end{array}$ & $\begin{array}{l}\text { - Persistence, Strength and } \\
\text { constancy-positive affect }(\mathrm{r}=0.50, \\
p<0.01) \text { and negative affect }(\mathrm{r}=-0.25, \\
p<0.01) \text {. } \\
\text { - Positive Reappraisals with positive affect } \\
(\mathrm{r}=0.44, p<0.01) \text { and negative affect } \\
(\mathrm{r}=-0.30, p<0.01) .\end{array}$ \\
\hline 9 & $\begin{array}{l}\text { Howard and } \\
\text { William [54] }\end{array}$ & $\begin{array}{l}\text { To assess the extent to which early } \\
\text { self-regulation and early changes in } \\
\text { self-regulation are associated with } \\
\text { adolescent academic, health, and } \\
\text { mental well-being outcomes. }\end{array}$ & $\begin{array}{l}\text { Self-regulatory problems: } \\
\text { Difficulties controlling and } \\
\text { sustaining attention, Difficulties } \\
\text { controlling behavior (restless or } \\
\text { overactive) and Difficulties } \\
\text { controlling emotions }\end{array}$ & $\begin{array}{l}\text { Subjective well-being: } \\
\text { Positive and negative affect } \\
\text { (anxiety and stress) }\end{array}$ & $\begin{array}{l}\mathrm{N}=4893 \\
\text { Gender: } 51 \% \mathrm{M}, 49 \% \mathrm{~F} \\
\mathrm{M}_{\text {age: }} \text { T1- }-4-5 \text { years } \\
\text { T2- } 6-7 \text { years and T3- } \\
\text { 14-15 years. } \\
\text { Desing: Longitudinal }\end{array}$ & $\begin{array}{l}\text { Control and sustain attention, are } \\
\text { associated with almost a 2-times increase } \\
\text { in depression (OR: } 1.73, p<0.01 \text {, CI } 95 \% \\
\text { [1.51-1.94]) and anxiety conditions (OR: } \\
1.70, p<0.01 \text {, CI } 95 \% \text { [1.48-1.91]). }\end{array}$ \\
\hline 10 & Kornienko et al. [48] & $\begin{array}{l}\text { Examine control effort and its } \\
\text { relationships with personality and } \\
\text { well-being. }\end{array}$ & $\begin{array}{l}\text { Internalizing problems: Identify } \\
\text { emotional difficulties and peer } \\
\text { problems } \\
\text { Externalizing problems: Conduct } \\
\text { problems and hyperactivity } \\
\text { Executive function: Activation } \\
\text { control, Attention focusing, } \\
\text { Inhibitory control ... }\end{array}$ & $\begin{array}{l}\text { Subjective well-being: } \\
\text { Satisfaction with life }\end{array}$ & $\begin{array}{l}\mathrm{N}=614 \\
\text { Gender: } 55 \% \mathrm{~F}(338) \& 45 \% \\
\mathrm{M}(276) \\
\mathrm{M}_{\text {age }}: \mathrm{M}=8.6, \mathrm{SD}=1.1 \\
\text { Desing: Cross-sectional }\end{array}$ & $\begin{array}{l}\text { - Focus attention-life satisfaction } \\
(\beta=0.28, p<0.001) \\
\text { - Focus attention-emotional and/or peer } \\
\text { problems }(\beta=-0.85, p<0.001) \text {. } \\
\text { - Focusing attention-behavior problems } \\
\text { ( } \beta=-0.58, p<0.001) \text {. } \\
\text { - Inhibitory control-externalizing } \\
\text { problems }(\beta=-0.43, p<0.001) \text {. }\end{array}$ \\
\hline
\end{tabular}


Table A1. Cont.

\begin{tabular}{|c|c|c|c|c|c|c|}
\hline $\mathbf{N}$ & Author & Aim (s) of Study & Self-Regulatory Measure & Measure of Well-Being & $\begin{array}{c}\text { Participants and Method } \\
\text { Design }\end{array}$ & Findings \\
\hline 11 & Lazaro-Visa et al. [49] & $\begin{array}{l}\text { To analyze the influence that bullying } \\
\text { has on life satisfaction, taking into } \\
\text { account the sociodemographic } \\
\text { characteristics of the participants, their } \\
\text { personal competencies and the school } \\
\text { climate. }\end{array}$ & $\begin{array}{l}\text { Social attitudes and } \\
\text { problem-solving strategies: } \\
\text { Observation, Anticipation, } \\
\text { Retention of relevant information, } \\
\text { Search alternative solutions and } \\
\text { Reflection on the consequences } \\
\text { Emotional self-regulation: Ability } \\
\text { to repair negative emotional states }\end{array}$ & $\begin{array}{l}\text { Subjective well-being: } \\
\text { Satisfaction with life }\end{array}$ & $\begin{array}{l}\mathrm{N}=693 \\
\text { Gender: } 53.3 \% \mathrm{~F}, 43.8 \% \mathrm{M} \\
\mathrm{M}_{\text {age }} \mathrm{M}=12.98, \mathrm{SD}=1.78 \\
\text { Desing: Cross-sectional }\end{array}$ & $\begin{array}{l}\text { The ability to manage negative } \\
\text { emotions-Student satisfaction }(\beta=0.11 \text {, } \\
p<0.01) \text {. }\end{array}$ \\
\hline 13 & Perry et al. [55] & $\begin{array}{l}\text { To learn whether coping skills } \\
\text { moderate the effects of social support. } \\
\text { To learn whether social support from } \\
\text { teachers, parents, and peers can } \\
\text { predict self-regulated learning over } \\
\text { time. }\end{array}$ & $\begin{array}{l}\text { Coping strategies: Emotional } \\
\text { debriefing, Spiritually centered } \\
\text { coping, Maintaining harmony and } \\
\text { Communalism } \\
\text { Self-regulation: Metacognitive } \\
\text { learning strategies and Effort } \\
\text { management }\end{array}$ & $\begin{array}{l}\text { Quality of Life } \\
\text { Perceived social support } \\
\text { (Teachers, Parents and } \\
\text { Classmates) }\end{array}$ & $\begin{array}{l}\mathrm{N}=229 \\
\text { Gender: } 59 \% \mathrm{~F}, 41 \% \mathrm{M} \\
\mathrm{M}_{\text {age }}:(\mathrm{M}=15.71 ; \mathrm{SD}=1.24 \\
\text { Desing: Longitudinal }\end{array}$ & $\begin{array}{l}\text { - Self-regulation of learning-perceived } \\
\text { support from parents }(\mathrm{r}=0.26, p<0.01) \text {, } \\
\text { teachers }(\mathrm{r}=0.27, p<0.01) \text { and satisfaction } \\
\text { with peers }(\mathrm{r}=0.19, p<0.01) \text {. } \\
\text { - Emotional debriefing-Satisfaction with } \\
\text { parents and teachers }(\mathrm{r}=0.19, p<0.01) \\
\text { - Spiritually centered coping with } \\
\text { Satisfaction with teachers }(\mathrm{r}=0.21, \\
p<0.01) \text { and Satisfaction with parents } \\
(\mathrm{r}=0.20, p<0.01) \\
\text { - Maintaining harmony }(\mathrm{r}=0.23, p<0.01) \\
\&(\mathrm{r}=0.22, p<0.01) \text {, for satisfaction with } \\
\text { teachers and parents, respectively. }\end{array}$ \\
\hline 14 & Woodward et al. [51] & $\begin{array}{l}\text { To examine the extent to which } \\
\text { preschoolers' emotional and } \\
\text { behavioral self-regulation difficulties } \\
\text { were associated with an increased } \\
\text { risk of later mental health and } \\
\text { educational problems. }\end{array}$ & $\begin{array}{l}\text { General emotional self-regulation } \\
\text { Cognitive Functioning }\end{array}$ & $\begin{array}{l}\text { Subjective well-being: } \\
\text { Positive and negative } \\
\text { affect-presence of anxiety. }\end{array}$ & $\begin{array}{l}\mathrm{N}=223 \\
\text { Gender: } 51 \% \mathrm{M} \\
\mathrm{M}_{\text {age }} \text { : Different age ranges } \\
\text { Desing: Longitudinal }\end{array}$ & $\begin{array}{l}\text { Behavioral self-regulation as a relevant } \\
\text { predictor of ADHD }(\beta=-0.16, p<0.01) \text {, } \\
\text { conduct disorder }(\beta=-0.14, p<0.05) \text { and } \\
\text { anxiety disorders }(\beta=-0.14, p<0.01) \text {. }\end{array}$ \\
\hline
\end{tabular}




\section{Appendix B}

Table A2. Table of Excluded studies.

\begin{tabular}{lll}
\hline & \multicolumn{1}{c}{ Reference } & Exclusion Reason \\
\hline $\begin{array}{l}\text { Ali, S.; De Araújo Pio, C. S.; Chaves, G. S. S.; Britto, R.; Cribbie, R.; Grace, S. L. Psychosocial well-being } \\
\text { over the two years following cardiac rehabilitation initiation \& association with heart-health behaviors. } \\
\text { General Hospital Psychiatry 2018, 52, 48-57. }\end{array}$ & $\begin{array}{l}\text { Not educational } \\
\text { context }\end{array}$ \\
\hline $\begin{array}{l}\text { Andrés, M. L.; Castañeiras, C. E.; Richaud, M. C. Relaciones entre la personalidad y el bienestar } \\
\text { emocional en niños. El rol de la regulación emocional. Cuadernos de Neuropsicología/Panamerican Journal of } \\
\text { Neuropsychology 2014, 8(2), 217-226. }\end{array}$ & $\begin{array}{l}\text { Not educational } \\
\text { context }\end{array}$
\end{tabular}

Balkis, M.; Duru, E. Procrastination, self-regulation failure, academic life satisfaction, and affective

3 well-being: underregulation or misregulation form. European Journal of Psychology of Education 2016, 31, Not in Europe 439-459.

4 Barlow, M. A.; Wrosch, C.; Mcgrath, J. J. Goal adjustment capacities and quality of life: A meta-analytic review. Journal of Personality 2020, 88, 307-323. https:/ / doi.org/10.1111/jopy.12492.

Meta-analysis

Beerten-Duijkers, J. C.; Vissers, C. T. W.; Rinck, M.; Barkley, R. A.;Egger, O. I. Self-Directedness Positively

5 Contributes to Resilience and Quality of Life: Findings From a Mixed Psychiatric Sample. Journal of Social and Clinical Psychology 2020, 39(1), 59-76. https:/ /doi.org/10.1521/jscp.2020.39.01.002.

Blanckenburg, P.; Seifart, U.; Conrad, N.; Exner, C.; Rief, W.; Nestoriuc, Y. Quality of life in cancer

6 rehabilitation: the role of life goal adjustment. Psycho-Oncology 2014, 23(10), 1149-1156. https://doi.org/10.1002/pon.3538.

Blasczyk-Schiep, S.; Adamczewska, K.; Sokoła, K. F. Subclinical eating disorder symptoms and positive

7 vs. negative affect in high school students: the mediating role of self-regulation. Current Issues in Personality Psychology 2019, 7(2), 120-131. https://doi.org/10.5114/cipp.2019.83125.

Briki, W. Trait self-control: Why people with a higher approach (avoidance) temperament can experience

8 higher (lower) subjective well-being. Personality and Individual Differences 2018, 120, 112-117. https://doi.org/10.1016/j.paid.2017.08.039.

Briki, W. Why do exercisers with a higher trait self-control experience higher subjective well-being? The

9 mediating effects of amount of leisure-time physical activity, perceived goal progress, and self-efficacy. Personality and individual differences 2018, 125, 62-67. https://doi.org/10.1016/j.paid.2017.12.020.

10 Calmeiro, L.; Camacho, I.; de Matos, M. G. Life satisfaction in adolescents: the role of individual and social health assets. The Spanish journal of psychology 2018, 21. https://doi.org/10.1017/sjp.2018.24. Cartmel, J.; Udah, H.; San Gil, O.; Prause, A. Self-regulation, behaviours and learning among children:

11 An evaluation of the Journey to the Island of Calm programme in Australia. Children Australia 2019, 44(3), 126-135. https://doi.org/10.1017/cha.2019.9.

Cervantes Arreola, D. I.; Valadez Sierra, M. D.; Valdés Cuervo, A. A.; Tánori Quintana, J. Diferencias en

12 autoeficacia académica, bienestar psicológico y motivación al logro en estudiantes universitarios con alto y bajo desempeño académico. Psicología desde el Caribe 2018, 35(1), 7-17.

Chew, H. S. J.; Sim, K. L. D., Cao, X. Motivation, challenges and self-regulation in heart failure self-care:

13 A theory-driven qualitative study. International journal of behavioral medicine 2019, 26(5), 474-485. http://doi.org/10.1007/s12529-019-09798-z.

Coffey, L.; Gallagher, P.; Desmond, D.; Ryall, N. Goal pursuit, goal adjustment, and affective well-being

14 following lower limb amputation. British journal of health psychology 2014, 19(2), 409-424. https://doi.org/10.1111/bjhp.12051.

15 Cosme, D.; Berkman, E. T. Autonomy can support affect regulation during illness and in health. Journal of health psychology 2020, 25(1), 31-37. https://doi.org/10.1177\%2F1359105318787013.

Not educational context

Not educational context

Not educational context

Not educational context

Not educational context

\section{Not srl in} well-being

Not srl in well-being

Not srl in well-being

Not educational context

Not educational context

Not educational context

Côté, S.; Gyurak, A.; Levenson, R. W. The ability to regulate emotion is associated with greater

16 well-being, income, and socioeconomic status. Emotion 2010, 10(6), 923. https://psycnet.apa.org/doi/10.1037/a0021156.

Not educational context

Day, J.; Freiberg, K.; Hayes, A.; Homel, R. Towards scalable, integrative assessment of children's

17 self-regulatory capabilities: New applications of digital technology. Clinical child and family psychology review 2019, 22(1), 90-103. http: / /doi.org/10.1007/s10567-019-00282-4. 
Table A2. Cont.

Reference

Exclusion Reason

De La Fuente, J.; Zapata Sevillano, L.; Peralta, F. J.; López, M.. Relación entre el aprendizaje autorregulado (proceso), la satisfacción y el rendimiento con el engagement-Bournout, (producto). International Journal of Developmental and Educational Psychology Revista INFAD De Psicología 2016, 4(1), 133-138. http://doi.org/10.17060/ijodaep.2014.n1.v4.597.

De la Fuente, J.; López, M.; Zapata, L.; Sander, P.; Putwain, D. Relación entre la autorregulación personal

19 y la confianza académica (presagio) con el engagement-bournout de los estudiantes universitarios (producto). International Journal of Developmental and Educational Psychology 2014, 5(1), 17-22. http://doi.org/10.17060/ijodaep.2014.n1.v5.642.

De Ridder, D.; Gillebaart, M. Lessons learned from trait self-control in well-being: Making the case for

20 routines and initiation as important components of trait self-control. Health psychology review 2017, 11(1), 89-99. https://doi.org/10.1080/17437199.2016.1266275.

DeWall, C. N.; Gilman, R.; Sharif, V.; Carboni, I.; Rice, K. G. Left out, sluggardly, and blue: Low

21 self-control mediates the relationship between ostracism and depression. Personality and Individual Differences 2012, 53(7), 832-837. https:/ / doi.org/10.1016/j.paid.2012.05.025.

Dias, P. C.; Bastos, A. S.; Marzo, J. C.; del Castillo Rodríguez, J. A. G. Bienestar, calidad de vida y

22 regulación afectiva en adolescentes portugueses. Atención primaria 2016, 48(7), 432-439. https://doi.org/10.1016/j.aprim.2015.09.005.

Dijkhuis, R. R.; Ziermans, T. B.; Van Rijn, S.; Staal, W. G.; Swaab, H. Self-regulation and quality of life in

23 high-functioning young adults with autism. Autism 2017, 21(7), 896-906. https://doi.org/10.1177\%2F1362361316655525.

Dou, K.; Nie, Y. G.; Wang, Y. J.; Liu, Y. Z. The relationship between self-control, job satisfaction and life

24 satisfaction in Chinese employees: A preliminary study. Work 2016, 55(4), 797-803. https://doi.org/10.3233/WOR-162447.

Dubuc-Charbonneau, N.; Durand-Bush, N. Moving to action: the effects of a self-regulation intervention

25 on the stress, burnout, well-being, and self-regulation capacity levels of university student-athletes. Journal of Clinical Sport Psychology 2015, 9(2), 173-192. https:/ / doi.org/10.1123/jcsp.2014-0036.

Not srl in

well-being

Not srl in

well-being

Elbers, J.; McCraty, R. HeartMath approach to self-regulation and psychosocial well-being. Journal of

6 Psychology in Africa 2020, 30(1), 69-79. https:/ / doi.org/10.1080/14330237.2020.1712797.

Theoretical work

Not educational

context

Not educational

context

Not educational

context

Not educational

context

Not educational

context

Not educational

context

Elliot, A. J.; Sedikides, C.; Murayama, K.; Tanaka, A., Thrash, T. M.; Mapes, R. R. Cross-cultural generality

27 and specificity in self-regulation: Avoidance personal goals and multiple aspects of well-being in the United States and Japan. Emotion 2012, 12(5), 1031. https://psycnet.apa.org/doi/10.1037/a0027456.

Fiedler, S.; Pfaff, H.; Soellner, R.; Pförtner, T. K. Exploring the association between health literacy and

28 psychological well-being among industry managers in Germany. Journal of occupational and environmental medicine 2018, 60(8), 743-753. http:/ / doi.org/10.1097/jom.0000000000001324.

Not educational context

Not educational context

9 Fiorella, L. The science of habit and its implications for student learning and well-being. Educational Psychology Review 2020, 1-23. http:/ / doi.org/10.1007/s10648-020-09525-1.

Theoretical work

Firoozabadi, A.; Uitdewilligen, S.; Zijlstra, F. R. Solving problems or seeing troubles? A day-level study

30 on the consequences of thinking about work on recovery and well-being, and the moderating role of

self-regulation. European Journal of Work and Organizational Psychology 2018, 27(5), 629-641. https:/ /doi.org/10.1080/1359432X.2018.1505720.

Foerst, N. M.; Klug, J.; Jöstl, G.; Spiel, C.; Schober, B. Knowledge vs. action: discrepancies in university

31 students' knowledge about and self-reported use of self-regulated learning strategies. Frontiers in psychology 2017, 8, 1288. https:/ /doi.org/10.3389/fpsyg.2017.01288.

32 Frazier, L. D.; Barreto, M. L.; Newman, F. L. Self-regulation and eudaimonic well-being across adulthood. Experimental aging research 2012, 38(4), 394-410. https:/ / doi.org/10.1080/0361073X.2012.699367.

Not educational context

Not srl in well-being

Freire, T.; Teixeira, A. The influence of leisure attitudes and leisure satisfaction on adolescents' positive

33 functioning: The role of emotion regulation. Frontiers in psychology 2018, 9, 1349. https://doi.org/10.3389/fpsyg.2018.01349.

Freund, A. M.; Hennecke, M. Changing eating behaviour vs. losing weight: The role of goal focus for

34 weight loss in overweight women. Psychology E Health 2012, 27 (sup2), 25-42. https://doi.org/10.1080/08870446.2011.570867.

Not educational context

Not educational context

Not educational context 
Table A2. Cont.

\section{Reference}

Exclusion Reason

Geisler, F. C.; Vennewald, N.; Kubiak, T.; Weber, H. The impact of heart rate variability on subjective

35 well-being is mediated by emotion regulation. Personality and individual differences 2010, 49(7), 723-728. https://doi.org/10.1016/j.paid.2010.06.015.

Van Genugten, L.; Dusseldorp, E.; Massey, E. K.; van Empelen, P. Effective self-regulation change

36 techniques to promote mental well-being among adolescents: a meta-analysis. Health psychology review 2017, 11(1), 53-71. https://doi.org/10.1080/17437199.2016.1252934.

Gillham, J.; Adams-Deutsch, Z.; Werner, J.; Reivich, K.; Coulter-Heindl, V.; Linkins, M.; ... Contero, A.

37 Character strengths predict subjective well-being during adolescence. The Journal of Positive Psychology 2011, 6(1), 31-44. https://doi.org/10.1080/17439760.2010.536773.

Grunschel, C.; Patrzek, J.; Klingsieck, K. B.; Fries, S. “I'll stop procrastinating now!" Fostering specific

38 processes of self-regulated learning to reduce academic procrastination. Journal of Prevention $\mathcal{E}$ Intervention in the Community 2018, 46(2), 143-157. https: / / doi.org/10.1080/10852352.2016.1198166.

Hakun, J. G.; Findeison, M. A. Cognitive control moderates the health benefits of trait self-regulation in

39 young adults. Personality and Individual Differences 2020, 152, 109572. https://doi.org/10.1016/j.paid.2019.109572.

Hanke, S.; Rohmann, E.; Förster, J. Regulatory focus and regulatory mode-Keys to narcissists'(lack of)

40 life satisfaction?. Personality and Individual Differences 2019, 138, 109-116. https://doi.org/10.1016/j.paid.2018.09.039.

Not educational context

Meta-analysis

Not educational context

Not srl in

well-being

Hempel, M. E.; Taylor, J. E.; Connolly, M. J.; Alpass, F. M.; Stephens, C. V. Scared behind the wheel: what

41 impact does driving anxiety have on the health and well-being of young older adults?. International psychogeriatrics 2017, 29(6), 1027. http://doi.org/10.1017/S1041610216002271.

Not educational context

Not educational context

Not educational context

Hennessy, E. A.; Johnson, B. T.; Acabchuk, R. L.; McCloskey, K.; Stewart-James, J. Self-regulation

42 mechanisms in health behavior change: a systematic meta-review of meta-analyses, 2006-2017. Health Psychology Review 2020, 14(1), 6-42. https://doi.org/10.1080/17437199.2019.1679654.

Herrmann, M.; Brandstätter, V.; Wrosch, C. Downgrading goal-relevant resources in action crises: The

43 moderating role of goal reengagement capacities and effects on well-being. Motivation and Emotion 2019, 43(4), 535-553. http:/ / doi.org/10.1007/s11031-019-09755-z.

Hides, L.; Dingle, G.; Quinn, C.; Stoyanov, S. R.; Zelenko, O.; Tjondronegoro, D.; ... Kavanagh, D. J.

44 Efficacy and outcomes of a music-based emotion regulation mobile app in distressed young people:

randomized controlled trial. JMIR mHealth and uHealth. 2019, 7(1), e11482. http://doi.org/10.2196/11482.

45 Hofer, J.; Busch, H.; Kärtner, J. Self-regulation and well-being: The influence of identity and motives. European Journal of Personality 2011, 25(3), 211-224. https: / / doi.org/10.1002/per.789.

Meta-analysis

Not educational context

Not educational context

Not educational context

46 Hui, C. M.; Harris Bond, M. Relationship between social axioms and subjective well-being: The role of self-regulation. Journal of Psychology in Chinese Societies 2010, 11(1), 29.

Not educational context Janse, M.; Sprangers, M. A.; Ranchor, A. V.; Fleer, J. Long-term effects of goal disturbance and adjustment

47 on well-being in cancer patients. Quality of Life Research 2016, 25(4), 1017-1027. https://doi.org/10.1007/s11136-015-1139-8.

Not educational context

Kadzikowska-Wrzosek, R. Perceived stress, emotional ill-being and psychosomatic symptoms in high

48 school students: the moderating effect of self-regulation competences. Archives of Psychiatry and Psychotherapy 2012, 3, 25-33.

Kebbe, M.; Perez, A.; Buchholz, A.; McHugh, T. L. F.; Scott, S. S.; Richard, C.; . . Ball, G. D. Barriers and

49 enablers for adopting lifestyle behavior changes in adolescents with obesity: A multi-centre, qualitative study. PloS one 2018, 13(12), e0209219. https://doi.org/10.1371/journal.pone.0209219.

Kelly, A. C.; Zuroff, D. C.; Foa, C. L.; Gilbert, P. Who benefits from training in self-compassionate

50 self-regulation? A study of smoking reduction. Journal of social and Clinical Psychology 2010, 29(7), 727-755. https://doi.org/10.1521/jscp.2010.29.7.727.

Kelly, C.; Anthony, E. K.; Krysik, J. “How am I doing?" narratives of youth living in congregate care on

51 their social-emotional well-being. Children and Youth Services Review 2019, 103, 255-263. https://doi.org/10.1016/j.childyouth.2019.06.001.

Not educational context

Not educational context

Not educational context

Not educational context 
Table A2. Cont.

Reference

52 Khoo, G. S.; Graham-Engeland, J. E. The benefits of contemplating tragic drama on self-regulation and health. Health promotion international 2016, 31(1), 187-199. https://doi.org/10.1093/heapro/dau056.

Korpela, K. M.; Pasanen, T.; Repo, V.; Hartig, T.; Staats, H.; Mason, M.; . . Ward Thompson, C.

53 Environmental strategies of affect regulation and their associations with subjective well-being. Frontiers in psychology 2018, 9, 562. http:/ / doi.org/10.3389/fpsyg.2018.00562.

Krzemien, D.; Richard's, M. M.; Ayelén Biscarra, M. Conocimiento experto y autorregulación en adultos

54 mayores jubilados profesionales y no profesionales. Avances en Psicología Latinoamericana 2018, 36(2), 331-344. http://dx.doi.org/10.12804/revistas.urosario.edu.co/apl/a.4793.

Lam, W. W.; Yeo, W.; Suen, J.; Ho, W. M.; Tsang, J.; Soong, I.; . . Kwong, A. Goal adjustment influence on

55 psychological well-being following advanced breast cancer diagnosis. Psycho-Oncology 2016, 25(1), 58-65. https://doi.org/10.1002/pon.3871.

56 Leist, A. K.; Müller, D. Humor types show different patterns of self-regulation, self-esteem, and well-being. Journal of Happiness Studies 2013, 14(2), 551-569. http:/ / doi.org/10.1007/s10902-012-9342-6.

Li, M.; Riis, J. L.; Ghazarian, S. R.; Johnson, S. B. Income, family context and self-regulation in 5-year-old

57 children. Journal of developmental and behavioral pediatrics: JDBP 2017, 38(2), 99. https: / /dx.doi.org/10.1097\%2FDBP.0000000000000380.

Liau, A. K.; Neihart, M.; Teo, C. T.; Goh, L. S.; Chew, P. A Quasi-experimental study of a fitbit-based

58 self-regulation intervention to improve physical activity, well-being, and mental health. Cyberpsychology, Behavior, and Social Networking 2018, 21(11), 727-734. https://doi.org/10.1089/cyber.2016.0502.

Livingstone, K. M.; Srivastava, S. Up-regulating positive emotions in everyday life: Strategies, individual

59 differences, and associations with positive emotion and well-being. Journal of Research in Personality 2012, 46(5), 504-516. https://doi.org/10.1016/j.jrp.2012.05.009.

60 Malhotra, R.; Suri, S. Locus of control and well-being among college students. Indian Journal of Positive Psychology 2017, 8(2), 231-236. https:/ /doi.org/10.15614/IJPP\%2F2017\%2FV8I2\%2F157196.

Mascia, M. L.; Agus, M.; Penna, M. P. Emotional Intelligence, Self-Regulation, Smartphone Addiction:

61 Which Relationship With Student Well-Being and Quality of Life?. Frontiers in Psychology 2020, 11, 375. https:// doi.org/10.3389/fpsyg.2020.00375.

Mattern, J.; Bauer, J. Does teachers' cognitive self-regulation increase their occupational well-being? The

62 structure and role of self-regulation in the teaching context. Teaching and Teacher Education 2014, 43, 58-68. https://doi.org/10.1016/j.tate.2014.05.004.

63 McCraty, R.; Zayas, M. A. Cardiac coherence, self-regulation, autonomic stability, and psychosocial well-being. Frontiers in psychology 2014, 5, 1090. https://doi.org/10.3389/fpsyg.2014.01090.

McNeill, K.; Durand-Bush, N.; Lemyre, P. N. Thriving, depleted, and at-risk Canadian coaches: Profiles

64 of psychological functioning linked to self-regulation and stress. International Sport Coaching Journal 2018, 5(2), 145-155. https://doi.org/10.1123/iscj.2017-0042.

65 Mehta, C.; Singh, T. Self-regulation and comorbid psychological problems among people with obesity and overweight. Indian Journal of Health $\mathcal{E}$ Well-being 2017, 8(6).

Mens, M. G.; Scheier, M. F. The benefits of goal adjustment capacities for well-being among women with

66 breast cancer: Potential mechanisms of action. Journal of personality 2016, 84(6), 777-788. https://doi.org/10.1111/jopy.12217.

Mesquita da Silva, S. M.; Boivin, J.; Gameiro, S. Self-regulation and well-being when facing a blocked

67 parenthood goal: A systematic review and meta-analysis. PloS one 2016, 11(6), e0157649. https://doi.org/10.1371/journal.pone.0157649.

Mikaeili, N.; Barahmand, U. Training in self-regulation enhances psychological well-being of distressed

68 couples. Procedia-Social and Behavioral Sciences 2013, 84, 66-69.

https://doi.org/10.1016/j.sbspro.2013.06.511.

Morales, S.; Ram, N.; Buss, K. A.; Cole, P. M.; Helm, J. L.; Chow, S. M. Age-related changes in the

69 dynamics of fear-related regulation in early childhood. Developmental science 2018, 21(5), e12633. https://doi.org/10.1111/desc.12633.
Exclusion Reason

Not educational

context

Not educational

context

Not educational

context

Not educational

context

Not srl in

well-being

Not educational context

Not educational

context

Not srl in

well-being

Not in Europe

Not educational

context

Not in students

Not educational

context

Not educational

context

Not educational

context

Not educational context

Meta-analysis

Not educational context

Not educational context 
Table A2. Cont.

\section{Reference}

Exclusion Reason

Morrish, L.; Rickard, N.; Chin, T. C.; Vella-Brodrick, D. A. Emotion regulation in adolescent well-being

70 and positive education. Journal of Happiness Studies 2018, 19(5), 1543-1564.

http:/ / doi.org/10.1007/s10902-017-9881-y.

71 Nagar, I. Self-regulation for sustaining happiness and well-being: An Indian perspective. Psychological Studies 2018, 63(2), 181-186. http:/ / doi.org/10.1007/s12646-017-0403-0.

72 Neff, K. D.; Faso, D. J. Self-compassion and well-being in parents of children with autism. Mindfulness 2015, 6(4), 938-947. http:/ /doi.org/10.1007/s12671-014-0359-2.

Neuenschwander, R.; Friedman-Krauss, A.; Raver, C.; Blair, C. Teacher stress predicts child executive

73 function: Moderation by school poverty. Early Education and Development 2017, 28(7), 880-900. https://doi.org/10.1080/10409289.2017.1287993.

Nicholls, A. R.; Levy, A. R.; Carson, F.; Thompson, M. A.; Perry, J. L. The applicability of self-regulation

74 theories in sport: goal adjustment capacities, stress appraisals, coping, and well-being among athletes. Psychology of Sport and Exercise 2016, 27, 47-55. https:/ / doi.org/10.1016/j.psychsport.2016.07.011.

Nikmanesh, Z.; Shirazi, M.; Farazinezhad, F. Examining the predictive role of emotional self-regulation

75 in quality of life and perception of suffering among patients with breast cancer. Middle East Journal of Cancer 2017, 8(2), 93-101.

Ortner, C. N.; Chadwick, L.; Wilson, A. M. Think ahead before you regulate: A focus on future

76 consequences predicts choices of and beliefs about strategies for the down-regulation of negative emotions. Motivation and Emotion 2018, 42(6), 896-908. https:/ /doi.org/10.1007/s11031-018-9716-0.

Theoretical work

Not educational

context

Not educational

context

Not in students

Pandey, A.; Hale, D.; Das, S.; Goddings, A. L.; Blakemore, S. J.; Viner, R. M. Effectiveness of universal

77 self-regulation-based interventions in children and adolescents: A systematic review and meta-analysis. JAMA pediatrics 2018, 172(6), 566-575. http://doi.org/10.1001/jamapediatrics.2018.0232.

Parker, P. D.; Martin, A. J.; Colmar, S.; Liem, G. A. Teachers' workplace well-being: Exploring a process

78 model of goal orientation, coping behavior, engagement, and burnout. Teaching and Teacher Education 2012, 28(4), 503-513. https://doi.org/10.1016/j.tate.2012.01.001.

Peh, C. X.; Kua, E. H.; Mahendran, R. Hope, emotion regulation, and psychosocial well-being in patients

79 newly diagnosed with cancer. Supportive Care in Cancer 2016, 24(5), 1955-1962. http://doi.org/10.1007/s00520-015-2989-x.

Pettemeridou, E.; Kennedy, M. R.; Constantinidou, F. Executive functions, self-awareness and quality of

80 life in chronic moderate-to-severe TBI. NeuroRehabilitation 2020, 1-10. http:/ / doi.org/10.3233/NRE-192963.

Pfattheicher, S.; Sassenrath, C. A regulatory focus perspective on eating behavior: how prevention and

81 promotion focus relates to emotional, external, and restrained eating. Frontiers in psychology 2014, 5, 1314. https://doi.org/10.3389/fpsyg.2014.01314.

Rabin, L. A.; Fogel, J.; Nutter-Upham, K. E. Academic procrastination in college students: The role of

82 self-reported executive function. Journal of clinical and experimental neuropsychology 2011, 33(3), 344-357. https:/ / doi.org/10.1080/13803395.2010.518597.

Ramírez-Maestre, C.; Esteve, R.; López-Martínez, A. E.; Serrano-Ibáñez, E. R.; Ruiz-Párraga, G. T.; Peters,

83 M. Goal adjustment and well-being: The role of optimism in patients with chronic pain. Annals of Behavioral Medicine 2019, 53(7), 597-607. https:/ / doi.org/10.1093/abm/kay070.

84 Reyes Martín, S.; Ferragut, M. Fortalezas psicológicas y diferencias de sexo en adolescentes. Escritos de Psicología (Internet) 2016, 9(3), 28-36. http://dx.doi.org/10.5231/psy.writ.2016.2811.

Not educational

context

Not educational context

Not educational context

Meta-analysis

Not in students

Not educational context

Not educational context

Not educational context

Not srl in well-being

Not educational context

Not educational context

Rodríguez-Fernández, A.; Ramos-Díaz, E.; Madariaga, J. M.; Arrivillaga, A.; Galende, N. Steps in the

85 construction and verification of an explanatory model of psychosocial adjustment. European Journal of Education and Psychology 2016, 9(1), 20-28. https://doi.org/10.1016/j.ejeps.2015.11.002.

Not srl in

well-being

Segar, M. L.; Eccles, J. S.; Richardson, C. R. Rebranding exercise: closing the gap between values and

86 behavior. International journal of behavioral nutrition and physical activity 2011, 8(1), 94. http://doi.org/10.1186/1479-5868-8-94.

Not educational context

Selwyn, J.; Grant, A. M. Self-regulation and solution-focused thinking mediate the relationship between

87 self-insight and subjective well-being within a goal-focused context: An exploratory study. Cogent Psychology 2019, 6(1), 1695413. http:/ /doi.org/10.1080/23311908.2019.1695413.

Not educational context 
Table A2. Cont.

Reference

Exclusion Reason

Sharbafshaaer, M. Correlation between dimensions of psychological well-being with life satisfaction and self-regulation. Journal of Fundamentals of Mental Health 2019, 21(3), 160-66.

Not educational

context

Shinan-Altman, S.; Afuta-Goldstein, S. Contribution of the self-regulation model to understanding the

89 health related quality of life of rheumatoid arthritis patients. Quality of Life Research 2020, 29(2), 403-412. http://doi.org/10.1007/s11136-019-02315-5.

Sieber, V.; Flückiger, L.; Mata, J.; Bernecker, K.; Job, V. Autonomous goal striving promotes a nonlimited

90 theory about willpower. Personality and Social Psychology Bulletin 2019, 45(8), 1295-1307. https://doi.org/10.1177\%2F0146167218820921.

Not educational

context

Simon, C. R.; Durand-Bush, N. Does self-regulation capacity predict psychological well-being in

91 physicians?. Psychology, Health \& Medicine 2015, 20(3), 311-321

https://doi.org/10.1080/13548506.2014.936887.

92 Singh, S.; Sharma, N. R. Self-regulation as a correlate of psychological well-being. Indian Journal of Health and Well-being 2018, 9(3), 441-444.

Not educational context

Not educational context

Not educational context

Somerville, M. P.; Whitebread, D. Emotion regulation and well-being in primary classrooms situated in

93 low-socioeconomic communities. British Journal of Educational Psychology 2019, 89(4), 565-584 https://doi.org/10.1111/bjep.12222.

Strauman, T. J.; Eddington, K. M. Treatment of depression from a self-regulation perspective: Basic

94 concepts and applied strategies in self-system therapy. Cognitive therapy and research 2017, 41(1), 1-15. http:/ / doi.org/10.1007/s10608-016-9801-1.

Suls, J.; Mogavero, J. N.; Falzon, L.; Pescatello, L. S.; Hennessy, E. A.; Davidson, K. W. Health behaviour change in cardiovascular disease prevention and management: meta-review of behaviour change techniques to affect self-regulation. Health Psychology Review 2020, 14(1), 43-65. https://doi.org/10.1080/17437199.2019.1691622.

Qualitative

Not educational context

Sweeney, A. M.; Wilson, D. K.; Loncar, H.; Brown, A. Secondary benefits of the families improving

96 together (FIT) for weight loss trial on cognitive and social factors in African American adolescents. International Journal of Behavioral Nutrition and Physical Activity 2019, 16(1), 47. http:/ /doi.org/10.1186/s12966-019-0806-5.

Tavakolizadeh, J.; Yadollahi, H.; Poorshafei, H. The role of Self regulated learning strategies in

97 psychological well being condition of students. Procedia-Social and Behavioral Sciences 2012, 69, 807-815. https://doi.org/10.1016/j.sbspro.2012.12.002.

Traeger, L.; Penedo, F. J.; Benedict, C.; Dahn, J. R.; Lechner, S. C.; Schneiderman, N.; Antoni, M. H.

98 Identifying how and for whom cognitive-behavioral stress management improves emotional well-being among recent prostate cancer survivors. Psycho-Oncology 2013, 22(2), 250-259. https://doi.org/10.1002/pon.2074.

Tsotsi, S.; Broekman, B. F.; Sim, L. W.; Shek, L. P.; Tan, K. H.; Chong, Y. S.; . . Rifkin-Graboi, A. Maternal

99 Anxiety, Parenting Stress, and Preschoolers' Behavior Problems: The Role of Child Self-Regulation. Journal of Developmental \& Behavioral Pediatrics 2019, 40(9), 696-705. http://doi.org/10.1097/DBP.0000000000000737.

Urrego Betancourt, Y.; Castro-Muñoz, J. A. Psychosocial Risk Factors: its Relation with Social Cognition,

100 Emotional Regulation and Well-Being. International Journal of Psychological Research 2019, 12(2), 17-28. https:/ / doi.org/10.21500/20112084.3741.

Uscanga, Y. C.; González, T. R.; del Moral Trinidad, L. E.; Hernández, N. I. C. Obesidad y autorregulación

101 de la actividad física y la alimentación en estudiantes universitarios: un estudio longitudinal. MHSalud: Revista en Ciencias del Movimiento Humano y Salud 2017, 14(1). https:/ / doi.org/10.15359/mhs.14-1.4.

Valenzuela, R.; Codina, N.; Castillo, I.; Pestana, J. V. Young university students' academic self-regulation

102 profiles and their associated procrastination: autonomous functioning requires self-regulated operations. Frontiers in Psychology 2020, 11. http:/ / doi.org/10.3389/fpsyg.2020.00354.

Van Damme, S.; De Waegeneer, A.; Debruyne, J. Do flexible goal adjustment and acceptance help

103 preserve quality of life in patients with multiple sclerosis?. International journal of behavioral medicine 2016, 23(3), 333-339. http:/ / doi.org/10.1007/s12529-015-9519-6.

Meta-analysis

Not educational context

Not srl in well-being

Not educational context

Not educational context

Not educational context

Not educational context

Not srl in well-being

Not educational context 
Table A2. Cont.

Reference

Exclusion Reason

Van Damme, S.; Kindt, S.; Crombez, G.; Goubert, L.; Debruyne, J. The relation between goal adjustment,

104 goal disturbance, and mental well-being among persons with multiple sclerosis. Psychology $\mathcal{E}$ Health 2019, 34(6), 645-660. https:// doi.org/10.1080/08870446.2018.1556272.

Vazeou-Nieuwenhuis, A.; Orehek, E.; Scheier, M. F. The meaning of action: Do self-regulatory processes

105 contribute to a purposeful life?. Personality and Individual Differences 2017, 116, 115-122. https://doi.org/10.1016/j.paid.2017.04.040.

Not educational

context

Veijalainen, J.; Reunamo, J.; Heikkilä, M. Early gender differences in emotional expressions and

106 self-regulation in settings of early childhood education and care. Early Child Development and Care 2019, 1-14. https://doi.org/10.1080/03004430.2019.1611045.

Vieira, P. N.; Mata, J.; Silva, M. N.; Coutinho, S. R.; Santos, T. C.; Minderico, C. S.; . . Teixeira, P. J.

107 Predictors of psychological well-being during behavioral obesity treatment in women. Journal of obesity 2011, 2011. http://doi.org/10.1155/2011/936153.

Vieira, P. N.; Silva, M. N.; Mata, J.; Coutinho, S. R.; Santos, T. C.; Sardinha, L. B.; Teixeira, P. J. Correlates

108 of health-related quality of life, psychological well-being, and eating self-regulation after successful weight loss maintenance. Journal of behavioral medicine 2013, 36(6), 601-610. http://doi.org/10.1007/s10865-012-9454-9.

Wei, L.; Kang, J. Employing Emotion Regulation Strategies in Tracking Personal Fitness Progress.

109 International Journal of Human-Computer Interaction 2019, 35(12), 1115-1124. https://doi.org/10.1080/10447318.2018.1511024.

Wiese, C. W.; Tay, L.; Duckworth, A. L.; D’Mello, S.; Kuykendall, L.; Hofmann, W.; .. Vohs, K. D. Too

110 much of a good thing? Exploring the inverted-U relationship between self-control and happiness. Journal of Personality 2018, 86(3), 380-396. https:/ / doi.org/10.1111/jopy.12322.

111 Wong, E.; Tschan, F.; Semmer, N. K. Effort in emotion work and well-being: The role of goal attainment. Emotion 2017, 17(1), 67. https://psycnet.apa.org/doi/10.1037/emo0000196.

Wrosch, C.; Amir, E.; Miller, G. E. Goal adjustment capacities, coping, and subjective well-being: The

112 sample case of caregiving for a family member with mental illness. Journal of personality and social psychology 2011, 100(5), 934. https://psycnet.apa.org/doi/10.1037/a0022873.

113 Wrosch, C.; Sabiston, C. M. Goal adjustment, physical and sedentary activity, and well-being and health among breast cancer survivors. Psycho-Oncology 2013, 22(3), 581-589. https://doi.org/10.1002/ pon.3037.

Wrosch, C.; Scheier, M. F.; Miller, G. E. Goal adjustment capacities, subjective well-being, and physical

114 health. Social and Personality Psychology Compass 2013, 7(12), 847-860. https://doi.org/10.1111/spc3.12074.

Not educational context

Not srl in

well-being

Not educational

context

Not educational context

Yang, Z.; Asbury, K.; Griffiths, M. D. An exploration of problematic smartphone use among Chinese

115 university students: Associations with academic anxiety, academic procrastination, self-regulation and

5 subjective well-being. International Journal of Mental Health and Addiction 2019, 17(3), 596-614.

Not educational

context http://doi.org/10.1007/s11469-018-9961-1.

116 Yarnell, L. M.; Neff, K. D. Self-compassion, interpersonal conflict resolutions, and well-being. Self and Identity 2013, 12(2), 146-159. https:/ / doi.org/10.1080/15298868.2011.649545.

Not educational context

Not educational context

Not educational context

Not educational context

Not educational context

Not educational context

Not educational context

Zhang, S.; Shi, R.; Yun, L.; Li, X.; Wang, Y.; He, H.; Miao, D. Self-regulation and study-related health

117 outcomes: A structural equation model of regulatory mode orientations, academic burnout and

Not srl in engagement among university students. Social Indicators Research 2015, 123(2), 585-599.

http://doi.org/10.1007/s11205-014-0742-3. 


\section{Appendix C}

Table A3. Publication status of the articles selected for review.

\begin{tabular}{cccc}
\hline Article & Journal & Year & Impact Factor \\
\hline Aadland et al. [56] & Frontiers in Psychology & 2018 & 2.129 (Q2) \\
\hline Bruce et al. [43] & Psychology in the schools & 2019 & 1.134 (Q4) \\
\hline Cahua et al. [44] & $\begin{array}{c}\text { Panamerican Journal of } \\
\text { Neuropsychology }\end{array}$ & 2018 & - \\
\hline Elliot et al. [52] & Journal of Personality & 2011 & 2.440 (Q1) \\
\hline Formina et al. [53] & Behavioral Sciences & 2020 & 0.502 (Q2) \\
\hline Garcia et al. [45] & PeerJ & 2015 & 2.183 (Q1) \\
\hline Gaspar et al. [46] & $\begin{array}{c}\text { International Journal of Disability, } \\
\text { Development and Education }\end{array}$ & 2016 & 0.576 (Q4) \\
\hline Guilmette et al. [47] & Learning and Individual Differences & 2019 & 1.916 (Q2) \\
\hline Howard et al. [54] & Journal of Developmental \& Behavioral & 2018 & 2.256 (Q3) \\
\hline Kornienko et al. [48] & Psychology in Russia: State of the art & 2018 & 0.216 (Q2) \\
\hline Lazaro- Vista et al. [49] & Frontiers in psychology & 2019 & 2.067 (Q2) \\
\hline Litalien et al. [50] & Motivation and Emotion & 2013 & 1.844 \\
\hline Perry et al. [55] & Youth \& Society & 2018 & 2.523 (Q1) \\
\hline Woodward et al. [51] & The Clinical Neuropsychologist & 2016 & 1.564 (Q3) \\
\hline & & &
\end{tabular}

\section{References}

1. Adam, N.L.; Alzahri, F.B.; Cik Soh, S.; Abu Bakar, N.; Mohamad Kamal, N.A. Self-Regulated Learning and Online Learning: A Systematic Review. In Advances in Visual Informatics; Badioze Zaman, H., Smeaton, A.F., Shih, T.K., Velastin, S., Terutoshi, T., Jørgensen, B.N., Aris, H., Ibrahim, N., Eds.; Lecture Notes in Computer Science; Springer: Cham, Switzerland, 2017; Volume 10645. [CrossRef]

2. Broadbent, J.; Poon, W.L. Self-regulated learning strategies \& academic achievement in online higher education learning environments: A systematic review. Internet High. Educ. 2015, 27, 1-13. [CrossRef]

3. Dignath, C.; Büttner, G. Components of fostering self-regulatedlearning among students. A meta-analysis on intervention studies at primaryand secondary school level. Metacogn. Learn. 2008, 3, 231-264. [CrossRef]

4. Dignath, C.; Büttner, G.; Langfeldt, H. How can primary schoolstudents learn self-regulated learning strategies most effectively? A meta-analysis on self-regulation training programmes. Educ. Res. Rev. 2008, 3, 101-129. [CrossRef]

5. Haase, C.M.; Heckhausen, J.; Wrosch, C. Developmental regulation across the life span: Toward a new synthesis. Dev. Psychol. 2013, 49, 964-972. [CrossRef]

6. Honicke, T.; Broadbent, J. The influence of academic self-efficacy on academic performance: A systematic review. Educ. Res. Rev. 2016, 17, 63-84. [CrossRef]

7. Sitzmann, T.; Ely, K. A meta-analysis of self-regulated learning inwork-related training and educational attainment: What we know and wherewe need to go. Psychol. Bull. 2011, 137, 421-442. [CrossRef]

8. Barlow, M.A.; Wrosch, C.; Mcgrath, J.J. Goal adjustment capacities and quality of life: A meta-analytic review. J. Personal. 2020, 88, 307-323. [CrossRef]

9. Da Silva, S.M.; Boivin, J.; Gameiro, S. Self-Regulation and Well-being When Facing a Blocked Parenthood Goal: A Systematic Review and Meta-Analysis. PLoS ONE 2016, 23, e0157649. [CrossRef]

10. Hennessy, E.A.; Johnson, B.T.; Acabchuk, R.L.; Mccloskey, K.; Stewart-James, J. Self-regulation mechanisms in health behavior change: A systematic meta-review of meta-analyses, 2006-2017. Health Psychol. Rev. 2020, 14, 6-42. [CrossRef]

11. Pandey, A.; Hale, D.; Das, S.; Goddings, A.-L.; Blakemore, S.-J.; Viner, R.M. Effectiveness of Universal Self-regulation-Based Interventions in Children and Adolescents. JAMA Pediatrics 2018, 172, 566-575. [CrossRef]

12. Suls, J.; Mogavero, J.N.; Falzon, L.; Pescatello, L.S.; Hennessy, E.A.; Davidson, K.W. Health behaviour change in cardiovascular disease prevention and management: Meta-review of behaviour change techniques to affect self-regulation. Health Psychol. Rev. 2020, 14, 43-65. [CrossRef] [PubMed]

13. Van Genugten, L.; Dusseldorp, E.; Massey, E.K.; Van Empelen, P. Effective self-regulation change techniques to promote mental well-being among adolescents: A meta-analysis. Health Psychol. Rev. 2017, 11, 53-71. [CrossRef]

14. Diener, E. Subjective well-being. Psychol. Bull. 1984, 95, 542-575. [CrossRef] [PubMed] 
15. Schimmack, U. Methodological issues in the assessment of the affective component of subjective well-being. In Oxford Handbook of Methods in Positive Psychology; Oxford University Press: Oxford, UK, 2007; pp. 96-110.

16. Ryff, C.D. Happiness is everything, or is it? Explorations on the meaning of psychological well-being. J. Personal. Soc. Psychol. 1989, 57, 1069-1081. [CrossRef]

17. Ryff, C.D. Psychological well-being in adult life. Curr. Dir. Psychol. Sci. 1995, 4, 99-104. [CrossRef]

18. Schalock, R.L. The concept of quality of life: What we know and do not know. J. Intellect. Disabil. Res. 2004, 48, 203-216. [CrossRef]

19. Schalok, R.L.; Verdugo, M.Á. Calidad de Vida: Manual para Profesionales de la Educación, Salud y Servicios Sociales; Alianza Editorial: Madrid, Spain, 2003.

20. Schunk, D.H.; Zimmerman, B.J. Self-regulation and learning. In Handbook of Psychology: Educational Psychology, 2nd ed.; Reynolds, W.M., Miller, G.E., Weiner, I.B., Eds.; John Wiley: Hoboken, NJ, USA, 2013; Volume 7, pp. 45-68.

21. Allan, N.P.; Hume, L.E.; Allan, D.M.; Farrington, A.L.; Lonigan, C.J. Relations between inhibitory control and the development of academic skills in preschool and kindergarten: A meta-analysis. Dev. Psychol. 2014, 50, 2368-2379. [CrossRef]

22. Clark, C.A.; Pritchard, V.E.; Woodward, L.J. Preschool executive functioning abilities predict early mathematics achievement. Dev. Psychol. 2016, 46, 1176-1191. [CrossRef]

23. Solé-Ferrer, N.; Mumbardó-Adam, C.; Company-Romero, R.; Balmaña-Gelpí, N.; Corbella-Santomà, S. Instrumentos de evaluación de la autorregulación en población infanto-juvenil: Una revisión sistemática. Rev. Psicol. Clín. Niños Adolesc. 2019, 6, 36-43.

24. Kim, Y.; Deci, E.L.; Zuckerman, M. The development of the self-regulation of withholding negative emotions questionnaire. Educ. Psychol. Meas. 2002, 62, 316-336. [CrossRef]

25. Wehmeyer, M.L.; Schalock, R.L. Self-determination and quality of life: Implications for special education services and supports. Focus Except. Child. 2001, 33, 1-16.

26. Lucas, R.E.; Diener, E.; Suh, E. Discriminant validity of well-being measures. J. Personal. Soc. Psychol. 1996, 71, 616-628. [CrossRef]

27. Sheldon, K.M.; Ryan, R.M.; Deci, E.L.; Kasser, T. The independent effects of goal contents and motives on well-being: It's both what you pursue and why you pursue it. Personal. Soc. Psychol. Bull. 2004, 30, 475-486. [CrossRef]

28. Tuominen-Soini, H.; Salmela-Aro, K.; Niemivirta, M. Achievement goal orientations and academic well-being across the transition to upper secondary education. Learn. Individ. Differ. 2011, 22, 290-305. [CrossRef]

29. Carver, C.S.; Scheier, M.F. Stress-regulation, stress, and coping. In Handbook of Personality, 3rd ed.; John, O., Robins, R., Pervin, L., Eds.; Guilford Press: New York, NY, USA, 2008.

30. Steinmayr, R.; Heyder, A.; Naumburg, C.; Michels, J.; Wirthwein, L. School-Related and Individual Predictors of Subjective Well-Being and Academic Achievement. Front. Psychol. 2018, 9, 2631. [CrossRef] [PubMed]

31. Bücker, S.; Nuraydin, S.; Simonsmeier, B.A.; Schneider, M.; Luhmann, M. Subjective well-being and academic achievement: A meta-analysis. J. Res. Personal. 2018, 74, 83-94. [CrossRef]

32. Moffitt, T.E.; Arseneault, L.; Belsky, D.; Dickson, N.; Hancox, R.J.; Harrington, H.; Houts, R.; Poulton, R.; Roberts, B.W.; Ross, S.; et al. A gradient of childhood self-control predicts health, wealth, and public safety. Proc. Natl. Acad. Sci. USA 2011, 108, 2693-2698. [CrossRef]

33. Moffitt, T.E.; Poulton, R.; Caspi, A. Lifelong impact of early self-control. Am. Sci. 2013, 101, 352-359. [CrossRef]

34. Tavakolizadeh, J.; Yadollahi, H.; Poorshafei, H. The Role of Self Regulated Learning Strategies in Psychological well being Condition of Students. Procedia-Soc. Behav. Sci. 2012, 69, 807-815. [CrossRef]

35. Morosanova, V.I.; Bondarenko, I.N.; Fomina, T.G. Personality and Motivational Features and Conscious Self- Regulation in Early Adolescents with Different Dynamics of Psychological Well-Being. Psychol. Sci. Educ. 2019, 24, 5-21. [CrossRef]

36. Wrosch, C.; Scheier, M.F.; Miller, G.E.; Schulz, R.; Carver, C.S. Adaptive self-regulation of unattainable goals: Goaldisengagement, goal reengagement, and subjective well-being. Personal. Soc. Psychol. Bull. 2013, 29, 1494-1508. [CrossRef] [PubMed]

37. Moher, D.; Liberati, A.; Tetzlaff, J.; Altman, D.G. Preferred reporting items for systematic reviews and meta-analyses: The PRISMA statement. Ann. Intern. Med. 2009, 151, 264-269. [CrossRef] [PubMed]

38. Cohen, J. Statistical Power Analysis for the Behavioral Sciences, 2nd ed.; Lawrence Erlbaum Associates Inc.: Hillsdale, NJ, USA, 1988; p. 13.

39. Borenstein, M.; Hedges, L.V.; Higgins, J.P.T.; Rothstein, H.R. Introduction to Metanalysis; Wiley: Hoboken, NJ, USA, 2009.

40. Hedges, L.V.; Olkin, I. Statistical Methods for Meta-Análisis; Academic Press: Cambridge, MA, USA, 1985.

41. Sánchez- Meca, J. Meta-análisis de la investigacion. In Metodología en la Investigacion Sobre Discapacidad; Verdugo, M.A., Crespo, M., Badía, M., Arias, B., Eds.; Publicaciones del INICO: Salamanca, Spain, 2008.

42. Peterson, R.A.; Brown, S.P. On the use of beta coefficients in meta-analysis. J. Appl. Psychol. 2005, 90, 175. [CrossRef]

43. Bryce, C.I.; Alexander, B.L.; Fraser, A.M.; Fabes, R.A. Dimensions of hope in adolescence: Relations to academic functioning and well-being. Psychol. Sch. 2020, 57, 171-190. [CrossRef]

44. Cahua, J.C.H.; Gallegos, W.L.A.; Cohello, A.L.N. Predictive Model of Purpose of Life in Adolescents of Public Educational Institutions from Arequipa City. J. Neuropsychol. 2018, 12, 10. [CrossRef]

45. Garcia, D.; Jimmefors, A.; Mousavi, F.; Adrianson, L.; Rosenberg, P.; Archer, T. Self-regulatory mode (locomotion and assessment), well-being (subjective and psychological), and exercise behavior (frequency and intensity) in relation to high school pupils' academic achievement. PeerJ 2015, 3, e847. [CrossRef]

46. Gaspar, T.; Bilimória, H.; Albergaria, F.; Matos, M.G. Children with special education needs and subjective well-being: Social and personal influence. International Journal of Disability. Dev. Educ. 2016, 63, 500-513. [CrossRef] 
47. Guilmette, M.; Mulvihill, K.; Villemaire-Krajden, R.; Barker, E.T. Past and present participation in extracurricular activities is associated with adaptive self-regulation of goals, academic success, and emotional well-being among university students. Learn. Individ. Differ. 2019, 73, 8-15. [CrossRef]

48. Kornienko, O.S.; Petrenko, E.N.; Leto, I.V.; Fedorova, N.A.; Slobodskaya, H.R. Effortful control in primary schoolchildren: Links with personality, problem behaviour, academic achievement, and subjective well-being. Psychol. Russ. State Art 2018, 11, 2-18. [CrossRef]

49. Lázaro-Visa, S.; Palomera, R.; Briones, E.; Fernández-Fuertes, A.; Fernández-Rouco, N. Bullied adolescent's life satisfaction: Personal competencies and school climate as protective factors. Front. Psychol. 2019, 10, 1691. [CrossRef]

50. Litalien, D.; Lüdtke, O.; Parker, P.; Trautwein, U. Different pathways, same effects: Autonomous goal regulation is associated with subjective well-being during the post-school transition. Motiv. Emot. 2013, 37, 444-456. [CrossRef]

51. Woodward, L.J.; Lu, Z.; Morris, A.R.; Healey, D.M. Preschool self regulation predicts later mental health and educational achievement in very preterm and typically developing children. Clin. Neuropsychol. 2017, 31, 404-422. [CrossRef] [PubMed]

52. Elliot, A.J.; Thrash, T.M.; Murayama, K. A longitudinal analysis of self-regulation and well-being: Avoidance personal goals, avoidance coping, stress generation, and subjective well-being. J. Personal. 2011, 79, 643-674. [CrossRef] [PubMed]

53. Fomina, T.; Burmistrova-Savenkova, A.; Morosanova, V. Self-Regulation and Psychological Well-Being in Early Adolescence: A Two-Wave Longitudinal Study. Behav. Sci. 2020, 10, 67. [CrossRef]

54. Howard, S.J.; Williams, K.E. Early self-regulation, early self-regulatory change, and their longitudinal relations to adolescents' academic, health, and mental well-being outcomes. J. Dev. Behav. Pediatrics 2018, 39, 489-496. [CrossRef]

55. Perry, J.C.; Fisher, A.L.; Caemmerer, J.M.; Keith, T.Z.; Poklar, A.E. The role of social support and coping skills in promoting self-regulated learning among urban youth. Youth Soc. 2018, 50, 551-570. [CrossRef]

56. Aadland, K.N.; Aadland, E.; Andersen, J.R.; Lervåg, A.; Moe, V.F.; Resaland, G.K.; Ommundsen, Y. Executive function, behavioral self-regulation, and school related well-being did not mediate the effect of school-based physical activity on academic performance in numeracy in 10-year-old children. The active smarter kids (ASK) study. Front. Psychol. 2018, 9, 245. [CrossRef]

57. Zimmerman, B.J. Attaining self regulation: A social cognitive perspective. In Handbook of Self-Regulation; Boekaerts, M., Pintrich, P.R., Zeidner, M., Eds.; Academic Press: Cambridge, MA, USA, 2000; pp. 13-41.

58. Gestsdóttir, S.; Lerner, R.M. Intentional self-regulation and positive youth development in early adolescence: Findings from the 4-h study of positive youth development. Dev. Psychol. 2007, 43, 508-521. [CrossRef]

59. Emmons, R.A. Personal strivings: An approach to personality and subjective well-being. J. Personal. Soc. Psychol. 1986, 51, 1058-1068. [CrossRef]

60. Little, B.R. Personal projects: A rationale and method for investigation. Environ. Behav. 1983, 15, 273-309. [CrossRef]

61. Sheldon, K.M.; Elliot, A.J. Not all personal goals are personal: Comparing autonomous and controlled reasons for goals as predictors of effort and attainment. Personal. Soc. Psychol. Bull. 1998, 24, 546-557. [CrossRef]

62. Deci, E.L.; Ryan, R.M. The 'what' and 'why' of goal pursuits: Human needs and the selfdetermination of behavior. Psychol. Inq. 2000, 11, 227-268. [CrossRef]

63. Morosanova, V.I.; Bondarenko, I.N. Diagnostika Samoregulyatsii Cheloveka Diagnostics of Self-Regulation of Human; Kogito-Tsentr: Moscow, Russia, 2015; p. 304

64. Kruglanski, A.W.; Thompson, E.P.; Higgins, E.T.; Atash, M.N.; Pierro, A.; Shah, J.Y.; Spiegel, S. To "do the right thing" or to "just do it": Locomotion and assessment as distinct self-regulatory imperatives. J. Personal. Soc. Psychol. 2000, 79, 793-815. [CrossRef]

65. Wrosch, C.; Heckhausen, J.; Lachman, M.E. Primary and secondary control strategies for managing health and financial stress across adulthood. Psychol. Aging 2000, 15, 387-399. [CrossRef]

66. Frydenberg, E.; Lewis, R. Escala de Afrontamiento para Adolescentes; TEA Ediciones: Madrid, Spain, 1997.

67. Moos, R.H. Coping Responses Inventory; Psychological Assessment Resources: Lutz, FL, USA, 1993.

68. Grotberg, E.H. Resilience programs for children in disaster. Ambul. Child Health 2001, 7, 75-83. [CrossRef]

69. Moraleda, M.; González, A.; García-Gallo, J. Actitudes y Estrategias Cognitivas Sociales; TEA Ediciones: Madrid, Spain, 2004.

70. Salovey, P.; Mayer, J.D.; Goldman, S.L.; Turvey, C.; Palfai, T.P. Emotional attention, clarity, and repair: Exploring emotional intelligence using the Trait Meta-Mood Scale. In Emotion, Disclosure, E Health; Pennebaker, J.W., Ed.; American Psychological Association: Washington, DC, USA, 1995; pp. 125-154. [CrossRef]

71. Shields, A.C.D. Emotion regulation among school-age children: The development of a new criterion Q-sort scale. Dev. Psychol. 1997, 33, 906-916. [CrossRef] [PubMed]

72. Pintrich, P.R.; De Groot, E.V. Motivational and self-regulated learning components of classroom academic performance. J. Educ. Psychol. 1990, 82, 33-40. [CrossRef]

73. Gaylord-Harden, N.K.; Utsey, S.O. The Africultural Coping System Inventory Youth Version (Y-ACSI); Unpublished Manuscript; Loyola University: Chicago, IL, USA, 2007.

74. Goodman, R. Psychometric properties of the Strengths and Difficulties Questionnaire (SDQ). J. Am. Acad. Child Adolesc. Psychiatry 2001, 40, 1337-1345. [CrossRef]

75. Gestsdottir, S.; Von Suchodoletz, A.; Wanless, S.B.; Hubert, B.; Guimard, P.; Birgisdottir, F.; Gunzenhauser, C.; Mcclelland, M. Early Behavioral Self-Regulation, Academic Achievement, and Gender: Longitudinal Findings from France, Germany, and Iceland. Appl. Dev. Sci. 2014, 18, 90-109. [CrossRef] 
76. Simonds, J.; Rothbart, M.K. The Temperament in Middle Childhood Questionnaire (TMCQ): A computerized self-report measure of temperament for ages 7-10. In Proceedings of the Occasional Temperament Conference, Athens, GA, USA, 28-31 October 2004.

77. Simonds, J.; Kieras, J.; Rueda, M.; Rothbart, M. Effortful control, executive attention, and emotional regulation in 7-10-year-old children. Cogn. Dev. 2007, 22, 474-488. [CrossRef]

78. Bayley, N. The Bayley Scales of Infant Development-Revised; Psychological Corporation: San Antonio, TX, USA, 1993.

79. Watson, D.; Clark, L.A.; Tellegen, A. Development and validation of brief measures of positive and negative affect: The PANAS scales. J. Personal. Soc. Psychol. 1988, 54, 1063-1070. [CrossRef]

80. Pavot, W.; Diener, E.; Suh, E. The Temporal Satisfaction with Life Scale. J. Personal. Assess. 1998, 70, 340-354. [CrossRef]

81. Clarke, P.J.; Marshall, V.W.; Ryff, C.D.; Wheaton, B. Measuring Psychological Well-Being in the Canadian Study of Health and Aging. Int. Psychogeriatr. 2001, 13, 79-90. [CrossRef] [PubMed]

82. Crumbaugh, J.; Macholick, L. Manual of Instruction for the Purpose in Life Test; Viktor Frankl Institute: Munster, Alemania, 1969.

83. Diener, E.; Emmons, R.; Larsen, R.; Griffin, S. The Satisfaction with Life Scale. J. Personal. Assess. 1985, 49, 71-75. [CrossRef]

84. Mackinnon, A.; Jorm, A.; Christensen, H.; Korten, A.E.; Jacomb, P.; Rodgers, B. A short form of the Positive and Negative Affect Schedule: Evaluation of factorial validity and invariance across demographic variables in a community sample. Personal. Individ. Differ. 1999, 27, 405-416. [CrossRef]

85. Huebner, E.S. Initial development of the Student's Life Satisfaction Scale. Sch. Psychol. Int. 1991, 12, 231-240. [CrossRef]

86. Cummins, R.A.; Eckersley, R.; Lo, S.K.; Okerstrom, E.; Hunter, B.; Da-vern, M. Australian Unity Well-Being Index: Cumulative Psychometric Record. Report 9.0; Australian Centre on Quality of Life: Melbourne, Australia, 2003.

87. Byrne, D.G.; Davenport, S.C.; Mazanov, J. Profiles of adolescent stress: The development of the adolescent stress questionnaire (ASQ). J. Adolesc. 2007, 30, 393-416. [CrossRef]

88. Spitzer, R.L.; Kroenke, K.; Williams, J.B.W.; Löwe, B. A brief measure for assessing generalized anxiety disorder: The GAD-7. Arch. Intern. Med. 2006, 166, 1092-1097. [CrossRef]

89. Goodman, R.; Ford, T.; Richards, H.; Gatward, R.; Meltzer, H. The development and well-being assessment: Description and initial validation of an integrated assessment of child and adolescent psychopathology. J. Child Psychol. Psychiatry 2000, 41, 645-655. [CrossRef]

90. Massé, R.; Poulin, C.; Dassa, C.; Lambert, J.; Bélair, S.; Battaglini, A. The Structure of Mental Health: Higher-Order Confirmatory Factor Analyses of Psychological Distress and Well-Being Measures. Soc. Indic. Res. 1998, 45, 475-504. [CrossRef]

91. Ravens-Sieberer, U.; Auquier, P.; Erhart, M.; Gosch, A.; Rajmil, L.; Bruil, J.; Power, M.; Duer, W.; Cloetta, B.; Czemy, L.; et al. The KIDSCREEN-27 quality of life measure for children and adolescents: Psychometric results from a cross-cultural survey in 13 European countries. Qual. Life Res. 2007, 16, 1347-1356. [CrossRef] [PubMed]

92. Metheny, J.; McWhirter, E.H.; O'Neill, M.E. Measuring perceived teacher support and its influence on adolescent career development. J. Career Assess. 2008, 16, 218-237. [CrossRef]

93. Keller, B.K.; Whiston, S.C. The role of parental influences on young adolescents' career development. J. Career Assess. 2008, 16, 198-217. [CrossRef]

94. Murdock, T.B. The social context of risk: Status and motivational predictors of alienation in middle school. J. Educ. Psychol. 1999, 91, 62-75. [CrossRef]

95. Eisenberg, N.; Eggum, N.; Vaughan, J.; Edwards, A. Relations of self-regulatory/control capacities to maladjustment, social competence, and emotionality. In Handbook of Personality and Self-Regulatio; Hoyle, R., Ed.; Wiley-Blackwell: Oxford, UK, 2010; pp. 21-46. [CrossRef]

96. Oberle, E.; Schonert-Reichl, K.A. Relations among peer acceptance, inhibitory control, and math achievement in early adolescence. J. Appl. Dev. Psychol. 2013, 34, 45-51. [CrossRef]

97. Sánchez-Pérez, N.; Fuentes, L.J.; Pina, V.; López-López, J.A.; González-Salinas, C. How do different components of Effortful Control contribute to children's mathematics achievement? Front. Psychol. Educ. Psychol. 2015, 6, 1383. [CrossRef] 